\title{
Guiding strategies for breeding vegetable cultivars
}

\author{
João Carlos da Silva Dias
}

Technical University of Lisbon, Instituto Superior de Agronomia, Tapada da Ajuda, Lisbon, Portugal; mirjsd@gmail.com

Received 29 October 2013; revised 11 December 2013; accepted 23 December 2013

Copyright (C) 2014 João Carlos da Silva Dias. This is an open access article distributed under the Creative Commons Attribution License, which permits unrestricted use, distribution, and reproduction in any medium, provided the original work is properly cited. In accordance of the Creative Commons Attribution License all Copyrights @ 2014 are reserved for SCIRP and the owner of the intellectual property João Carlos da Silva Dias. All Copyright (c) 2014 are guarded by law and by SCIRP as a guardian.

\section{ABSTRACT}

Vegetables are considered essential for wellbalanced diets. The production and marketing of vegetables crops are undergoing continuous change globally. This is mainly due to the growing demands of consumers for safe and healthy vegetables, increased urbanisation of societies, and the growth in scale and influence of supermarkets chains. Horticultural science can respond to many of these challenges through research, breeding and innovation that can seek to gain more efficient methods of crop production, refined post-harvest storage and handling methods, newer and higher value vegetable cultivars and demonstration of their health benefits. Vegetable breeding has to address and satisfy the needs of both the consumer and the producer. Innovation in vegetable breeding depends on specific knowledge, the development and application of new technologies, access to genetic resources, and capital to utilise them. The driving force behind this innovation is acquiring or increasing market share. Access to technology, as well as biodiversity, is essential for the development of new vegetable cultivars. A few multinational corporations, whose vast economic power has effectively marginalized the role of public sector breeding as well as local, small/medium-scale seed companies, dominate the global vegetable seed trade. For most vegetable crops, only a few multinational seed corporations are controlling large part of the world market. This situation makes a growing part of the global vegetable supply dependent on a few seed providers. The multinational seed corporations ensued from merging some small or medium vegetable breeding programs to reduce costs. There may be fewer vegetable breeders in the future and growers will rely on seeds with a narrow genetic base. In order to meet future needs of vegetable breeders it is important that educacional programs incorporate rapidly changing new technologies with classical content and methods. Active and positive connections between the private and public breeding sectors and large-scale gene banks are required to avoid a possible conflict involving breeders' rights, gene preservation and erosion. Horticulturists will need to develop cultural practices and vegetable breeders to breed vegetables for a multifunctional horticulture (diversity, health promotion, post-harvest, yearround suply, etc.) and to cope with harsher climate conditions and lower inputs than they have come to expect. Improved production systems that can cope with climate extremes must allow vegetables to produce under high temperatures, greater drought stress, increased soil salinity, and periodic flooding. This will involve a combination of improved vegetable cultivars and modified production systems.

\section{KEYWORDS}

Vegetables; Horticulture; Health Benefits; Marketing; Trading; Breeding; Year-Round Production; Sustainability

\section{VEGETABLES IN THE WORLD}

\subsection{Human Diets}

Vegetables are grown worldwide in almost 200 countries and make up a major portion of the diet of humans in many parts of the world and play a significant role in human nutrition, especially as sources of vitamins (C, A, B1, B6, B9, E), minerals, dietary fiber and phytochemicals [1]. They can be also a major source of protein for the poor. Vegetables in the daily diet have been strongly 
associated with improvement of gastrointestinal health, good vision, and reduced risk of heart disease, stroke, chronic diseases such as diabetes, and some forms of cancer [2]. Low vegetable intake, in unbalanced diets, has been estimated to cause about $31 \%$ of ischaemic heart disease and $11 \%$ of stroke worldwide. The International Agency for Research on Cancer (IARC) estimates that the preventable percentage of cancer due to such diets ranges from 5\% - 12\% for all cancers, and 20\% - 30\% for upper gastrointestinal tract cancers. Some phytochemicals of vegetables are strong antioxidants and are thought to reduce the risk of chronic disease by protecting against free-radical damage, by modifying metabolic activation and detoxification of carcinogens, or even influencing processes that alter the course of tumor cells [2]. "Hidden hunger" or micronutrient and vitamin deficiencies is a pernicious problem around the world that is caused by a lack of vitamins and minerals such as vitamin A, iodine and iron in the human diet. It affects the health of between 2 and 3.5 billion people in the developing world and increases the risk of illness or death from infectious diseases and children do not develop to their full physical or mental potential [1,2]. In much of South Asia and sub-Saharan Africa, dietary deficiencies of iron and vitamin A are major health problems, resulting in millions of deaths each year. Iron deficiency anemia is one of the world's most prevalent dietary deficiencies. In a recent report on the world nutrition situation, the United $\mathrm{Na}$ tions (UN) estimated that 4 to 5 billion people are affected by iron deficiency anemia, with the most severe incidence in South Asia and sub-Saharan Africa. Its effects on cognitive development, fatigue and mortality have significant economic impacts, estimated at $7.9 \%$ of GDP in the case of Bangladesh [3]. Vitamin A deficiency also is widespread and an estimated 190 million preschool children and 19 million pregnant women are affected. More than half of these are found in South and East Asia and under a third in Africa [4]. Vitamin A deficiency is a major cause of blindness and weakened resistance to disease, resulting in the deaths of up to 3 million children each year [1-3]. In Bangladesh, Cambodia, Nepal and the Philippines at least half of the preschool children and pregnant women are affected by micronutrient and vitamin deficiencies [5]. Small variation in maternal diets, particularly reduction in micronutrient content, can have a significant impact on fetal growth and development. The interplay of the different micronutrients and antioxidants found in vegetables has important health impacts, explaining for instance the higher birth weight of children in India, when mothers consumed higher rates of green leafy vegetables and fruits during pregnancy [6]. Diets rich in vegetables, in all their many forms to ensure an adequate intake of most micronutrients, dietary fibers, and phytochemicals can bring a much-needed measure of balance back to diets contributing to solve many of these nutrition problems [2,7].

Good health depends on dietary diversity, and as poverty increases, human diets become less diverse. In impoverished countries the poor have little choice and are forced to rely on the cheapest available staples (and eventually vegetables) and dietary diversity and health suffer. In richer countries, changes in the food systems have made poor quality processed foods high in carbohydrates and fats more affordable, available, and accessible; this has most impact on the diets of the poor [8]. A long term global focus on ensuring supplies of vegetable and staple crops has come at the expense of dietary diversity. The emphasis has been on ensuring supplies of macronutrients while putting less emphasis on major sources of micronutrients and vitamins, which means a focus on survival rather than on health. World vegetable production does not meet even the basic nutritional needs of most countries, and the resulting imbalanced diets are one of the world's most serious health problems. Continuing to focus on increasing the production of staples will only exacerbate the real food problem, which is one of imbalanced diets.

A world vegetable survey showed that 402 vegetable crops are cultivated worldwide, representing 69 families and 230 genera $[9,10]$. Vegetable crops, of which the leaves or young leafy shoots are consumed, were the most common group of vegetables utilized (53\% of the total), followed by vegetable fruits (15\%). Below ground crop vegetable organs ranked as follows in frequency of use: roots $>$ tubers $>$ rhizomes $>$ corms $>$ stolons and together comprised $17 \%$ of the total number. Many vegetable crops have more than one part used. Most of the vegetables are marketed fresh with only a small proportion processed because as most vegetables are perishable by nature, consumption shortly after harvest is the best guarantee for optimal quality. Of these marketed vegetables, only 67 (17\%) have attracted great breeding attention by international seed companies, due to their large area of production and substantial consumption, 52 (13\%) were considered minor, and other 87 (22\%) were considered rare [11,12]. In 2010 the global vegetable seed market was estimated at US\$4.1 billion, of which $36 \%$ were for solanaceous, $21 \%$ for cucurbits, $13 \%$ for roots and bulbs, $12 \%$ for large seed, $11 \%$ for brassicas, and $7 \%$ for leafy and others vegetables [13]. In the last 8 years global commercial vegetable seed sales had an annual growth rate of $5.8 \%$. There are now 7.2 billion human beings inhabiting this planet, and it has been projected that world population growth may exceed 70 million annually over the next 40 years. It is expected to reach approximately 9.5 billion by 2050, when approximately $90 \%$ of the global population will reside in Asia, Africa, and Latin American countries. With the increase in world 
population and consumption, and the advent of a high degree of growth and added value through biotechnology, the global market of vegetable seeds is expected to expand in future years.

\subsection{Consumption}

The worldwide consumption and importance of vegetables in the diet is difficult to estimate owing to scant production statistics. Even where crop reporting services are an integral part of the agricultural infrastructure, information is available only for a small percentage of the vegetable crops grown. The consumption and caloric contribution of vegetables to the diet varies widely with geographical region, nationality, local customs, and cuisine. China is the largest consumer of vegetables in the world. Vegetables make up about 35\% of per capita food consumption in China, a much higher share than the world average [14]. Besides India, other southern Asian countries such as Bangladesh, Cambodia, North and South Vietnam, Laos and Philippines are also high producers and great consumer of vegetables. For example, vegetables comprise $40 \%$ of the Bangladeshi diet [15]. Many vegetables are consumed near where they are produced, especially in China, India and other Asian countries. The per capita consumption of vegetables in Asia has increased considerably from $41 \mathrm{~kg}$ to $141 \mathrm{~kg}$ between 1975 and 2003 [16], particularly in China where the per capita consumption has increased from $43 \mathrm{~kg}$ (1975) to $154 \mathrm{~kg}$ (2003). In Africa, the per capita consumption of vegetables lags far behind the world average, with less than the FAO/WFO (World Food Organization) recommended minimum uptake of $200 \mathrm{~g}$ of vegetables/day (73 $\mathrm{kg} /$ year).

Rapid growth in mean per capita incomes in developed countries during the 1990s enabled consumers to purchase a broader range of relatively expensive vegetable commodities such as off-season produce, relatively new or renewed vegetables and organic produce. Higher incomes of consumers in developed countries have also raised the demand for other attributes such as better quality vegetables and more variation in the daily menu. In developing countries, consumption and domestic vegetable markets are also expanding because of an emerging educated middle class with increasing incomes. China, India and Indonesia, countries with the largest populations, have large emerging middle classes, which impact the demand for high-value vegetables [17]. Although the overall downturn in the globally economy over the past decade has seen a decrease in the discretionary income of consumers in many countries. As a consequence the consumption of many high priced items such as fresh vegetables has been static or declining. This has also impacted on the rate of growth in exports from some countries.
Globally, an increasing proportion of the world's population is living in urban environments where their interest in and knowledge of farming, and therefore of food production, is becoming increasingly deficient. In 1950 approximately $71 \%$ of the world's population lived in rural locations while in 2010 this had declined to 50\% (or as low as $10 \%, 18 \%$, and $22 \%$ for the United Kingdom, the USA and France, respectively), and is projected to be as low as $30 \%$ globally by 2050 [18]. There is, in all developed countries, a growing expectation and dependence on the supply of a low-cost, year-round supply of premium quality vegetables. Paradoxically, these same urban-based consumers have become increasing vocal about issues such as carbon taxes, the use of pesticides and safety of vegetables, labour conditions for farm workers, the sustainability of production methods, and the environmental conditions under which it is produced. These are often driven as "matters of conscience" and are in isolation from the reality of current production methods or of the opportunity to realistically meet these consumer demands. This trend, in turn, has led to the increased importance of organic vegetables and labeled brands $[19,20]$. Most of the total organic arable land for vegetables (213,453 ha) is located in Europe (74\%), followed by North America (20\%) and Latin America (3\%), but represents only $0.04 \%$ of the total area of vegetables in the world [21]. Organic vegetable trade from developing to developed countries is currently growing at over $20 \%$ per year [22] but represents only $3 \%$ of total vegetable production [21].

Populations in developed countries are also shifting dramatically towards greater proportions of older people as a consequence of the "baby boom" of the 1940s and 1960 s, and as a result of the lower birth rates in last recent decades. For example, in Japan and Europe (the two regions where severe population ageing will occur in the near future), within twenty years many countries will face a situation where the largest population cohort will be those over 65 and average age will be approaching 50 . These shifts are impacting strongly on consumer consumption patterns as evidenced by smaller households, increased dining out, and increased demands for healthier vegetabes and foods.

Desire for year-round availability, increased diversity, and growing health awareness, have also been important reasons for increased consumption of vegetables in developed countries. For example, the dietary benefit of fresh produce, is the major reason for the $25 \%$ increase in fresh vegetable consumption in the United States during the 1977-1999 period [23]. On the other hand, factors such as increased participation by women in the labor market have created demand for processed, ready-to-eat convenience vegetable products. 


\subsection{Diversification}

Consumers also want more vegetable diversification and a continuous supply. Vegetables are purchased partly based on eye appeal, which means that the development of desire to consume, increases market demand. Diversification also tends to increase consumption. Product differentiation, including new or renewed product introductions, is still a key strategy for expanding sales in vegetable markets. For example, the fresh tomato category has been differentiated to more than 10 offerings (beefsteak tomato, Roma type tomato, vine-ripe tomato, cocktail tomatoes on vine, tiny-plum tomatoes, mini-plum tomatoes, red cherry tomatoes on vine, attractive yellow and orange cherry tomatoes, mini San Marzano-type tomatoes, tear drop or pear shaped tomatoes, super or premium taste tomatoes). The introduction of specialty fresh baby leaf vegetable salads and fresh-cut products has opened new opportunities for domestic producers. The increased production of baby leaf vegetables in the world is intended to increase desire among elite consumers and is also an excellent way of supplying micronutrients. For example baby leaf curly kale, as well as other dark green leafy vegetables, is a rich source of lutein plus zeaxanthin carotenoids and when cooked contains seven times as much vitamin A as cooked broccoli and provides more calcium per $100 \mathrm{~g}$ than milk, yogurt, cooked broccoli or cooked spinach. Until recently kale was not a particularly popular vegetable in Europe (except Portugal), but as a baby leaf vegetable with 5 leaves, it is now accepted by many European consumers. An example of diversification in peas is the pea shoot. It is a nutritious leaf vegetable with high levels of vitamin C, folic acid and vitamin A. To exploit such opportunities, it is important to continue research and to disseminate information regarding the nutritional benefits of vegetables, develop new improved vegetable cultivars and lightly processed products, evaluate the economic opportunities and the market scope of these new products, and identify marketing trends and alternatives [12].

Increasingly, consumers also demand lightly processed, ready-to-eat vegetables and this is true not only for developed but also for developing countries. Lightly processed vegetables require appropriate packaging, such as plastic wrap, which is important to keep the cut vegetables fresh. New lightly processing and packaging technology enables fresh vegetables to be presented in a convenient format (e.g. increasing the shelf life of fresh pre-cut vegetables) while maintaining aspects of health, safety, and freshness. Providing customers with innovative combinations of products and services is the key to the lightly processed vegetables. The United States leads in the light processing industry, with estimated sales of USD\$13 billion in 2008 in both retail and foodservice, which is double the amount in 2000. Brands play an im- portant role in this segment. For example, the brands of Dole and Fresh Express together accounted for $88 \%$ of the United States packaged salad market in 2004. Vitacress is Europe's leading grower and packer of watercress, rocket, baby leaf salads, and other specialty vegetables. The growth rate in retail sales of lightly processed vegetables in several Asian countries over the past years has been tremendous. For example the total percentage of retail sales of processed vegetables during the 20012005 period in Vietnam, China, Indonesia, South Korea, Thailand, India and Philippines was 11.2\%, 9.6\%, 7.8\%, $6.8 \%, 6.1 \%, 6.0 \%$, and $5.1 \%$ respectively [24].

\section{VEGETABLE MARKETING AND SAFETY ISSUES}

\subsection{Vegetable Marketing}

Vegetables are often highly perishable products, restricting the ability of producers to store them in order to cope with price flutuations. They are also of specific high value and they are usually sold through specialized markets.

The supply chain for vegetables produce has changed rapidly on a global scale over the past two or three decades. Huge supermarket chains have rapidly displaced smaller marketers as the main outlets for the year-round supply of vegetables. Furthermore, the number of major supermarket chains is currently fairly static and is predicted to reduce further, although expansion of supermarkets all over the world and specialy in Asia is very significant. Consequently the buying power is being consolidated into fewer supermarket chain retailers with significant consequences to both primary producers and to buyers.The following characteristics are common for the produce buyers in most if not all these huge supermarket chains: i) a need for year-round supply to allow consumers continuity of access to specific vegetable items; ii) a wide range of interesting products to challenge the existing product range and to entice and retain consumers; iii) the best cultivars; iv) highest possible quality with regard to flavour, appearance, and condition; and v) competitive pricing.

Although some consumers in many developed countries have become more interested in understanding the sources of the vegetables that they eat. This has led to a proliferation of farmer markets in many areas, including those focussed on vegetable crops produced using organic farming methods, which have become increasingly popular amongst consumers. Nonetheless, the proportion of produce that these markets are selling is still comparatively so small, on a global scale, and is usually (but not always) limited to provision of products during the current growing season (the exception is where local producers sometimes supplement their own products with 
imported ones).

Currently more than $65 \%$ of the vegetables produced in the world are sold by vegetable growers to wholesale dealers or huge supermarket chains, and relatively few growers sell their product at retail prices to consumers in farmer markets [12]. Globally the horticultural product markets are still dominated by a large number of wholesalers or middle-men, which means not only that the producers have a lower profit, but also the consumer often does not have access to lower-priced vegetables. Globally growers only receive $30 \%$ or less of the retail price. This situation is a serious problem for growers.

Domestic and international markets for vegetables are changing rapidly all over the world, partially fuelled by the spread of huge supermarkets chains. The top ten global supermarket chains in 2012 were: Wal-Mart (from USA), Carrefour (from France), Tesko (from UK), Metro (from Germany), Kroger (from USA), Schwarz (from Germany), Costco (from USA), Home Depot (from USA), Target (from USA) and Aldi (from Germany). Consumers increasingly purchase their vegetables and other foods in large convenience stores such as these super and hypermarkets chains. The proliferation of supermarkets in developed and developing countries creates both challenges and opportunities for vegetable promducers [12]. Indeed supermarkets may contribute to a higher demand of horticultural products and increase expectations for quality, safety, and presentation, while simultaneously excluding small growers from participating in procurement and contracts. The importance of supermarkets is growing especially fast in the southeast Asia region. Supermarkets are expanding in China 30\% $40 \%$ per year, 2 - 3 times faster than other developing countries [12]. According to USDA, China could support at least 9100 hypermarkets [25]. In China growth of modern retailing markets is spreading from the early growth areas of Guangzhou, Shanghai and Beijing to inner western regions. This is already having a profound effect on the way that vegetables are produced in the country. In Indonesia, Malaysia, and Thailand, supermarkets account for 33\% of the market while in Taiwan and Philippines the figure is closer to 63\% [26]. The 10 supermarket chains with the highest growth rates in last decade included two supermarket chains from China and one from South Korea $[27,28]$. And in Indonesia the local retail supermarket chain Ramayana is growing at $25 \%$ a year [29]. The share of fresh vegetables sold through supermarkets in some countries and metropolitan areas of Asia such as Malaysia, Bangkok (Thailand), Manila (Philippines), South Korea and China is 35\%, 30\%, 15\%, $11 \%$ and $10 \%$, respectively [30]. In Vietnam, where modernization of food retailing is only about 10 years old, and where wet markets are still the major source of food shopping, the supermarket's share of vegetable pro- ducts increased from around $0.5 \%$ in 2000 to around $40 \%$ in 2007. The Metro supermarket chain has announced programs of assistance and consulting for 4000 growers and suppliers to help them to upgrade the quality, marketability, and competitiveness of their products [12].

Outside of southeast Asia, supermarket sales in Kenya are growing at $18 \%$ a year. They are expected to become the dominant urban food retailers by 2011 [31]. At Chile the supermaket Cencosud is growing at $30.5 \%$ a year $[27,28]$.

The growing importance of supermarket outlets has implications of its own, regarding their methods of procurement and their quality standards. Supermarkets in the cities bring quality to the shelves. Vegetables are well packed and presented, providing scope for premium quality as well as novelty items. The difficulties that growers can experience is reflected in fairly rapid declines in the numbers of growers involved, as companies tend to de-list suppliers who do not meet expectations in terms of volume, quality, and timely delivery. In Malaysia, for example, the Giant supermarket chain had 200 vegetable suppliers in 2001, but just 30 in 2003. In Thailand, similar changes have been seen following the introduction of a distribution center for the TOPS supermarket chain [30]. Small-scale growers can find it difficult to produce and deliver according to the supermarket chain's standards [12]. In Brazil the Wal-Mart supermarket chain has about 1500 associated growers producing vegetables, of which $90 \%$ are large producers and only $10 \%$ are small producers. The standards of quality, safety and presentation make it difficult for the small producers to compete. In Portugal and in other European countries the situation is similar. The market is getting more refined in terms of quality and yield expectations, and there is a clear demand for excellent hybrid vegetable cultivars [12,32]. Success for vegetable growers will depend on their ability to access diverse markets and respond promptly to changes in market conditions. Growers grow vegetables for immediate marketing and their produce is subject to competition to decide the prices. Hence they cannot compromise the quality of the seeds they use for fear of rejection of their produce. They buy the best seeds, mainly hybrids, and frequently try new products to remain successful. The seed companies in turn get instant response and success if they develop new promising hybrids. Price of seeds is a more critical factor in marginal vegetable areas, where capital and spending input regimes are low, but less important where high yields can be obtained and the grower's produce can be sold profitably [12,32].

\subsection{Safety Issues}

Food safety legislation in the European Union and in the United States is introducing increasingly stricter stan- 
dards. It is expected that the assurance of "safe" vegetable products will become increasingly important not only in these countries but all over the world. Human and environmental health risks of inapropriate vegetable production practices arise mainly from the following: i) innapropriate handling of pesticides by growers; ii) crop selection or location without due regard to the environment polution in the air, soil or water; iii) aplication of unsorted or insuficiently treated solid and liquid organic wastes to vulnerable crops; and iv) poor and unsanitary handling during marketing and distribution [12].

In general, vegetable production requires more plant protection products per hectare. Because of their cultivation intensity, vegetables suffer from many biological stresses including pests, diseases and weeds. Because of the diversity within and between plant families, their pest loads are far more varied and complex compared to field crops. Considerably fewer resources have been directed at improving their production and pest and disease management options, compared to field crops such as rice, wheat and maize [33]. Since vegetables are high value commodities with high "cosmetic" standards, the main method for controlling pathogens, pests, and weeds has been the use of pesticides. Vegetables are often consumed in fresh form, so pesticide residue and biological contamination in them is a serious issue. Vegetables account for a significant share of the global pesticide market. About $20 \%$ of the world's annual pesticides expenditures (amounting to US\$ 45 billion in 2009) are spent for growing vegetables [34]. Almost $25 \mathrm{~kg} / \mathrm{ha}$ of active pesticide substances are used on average in vegetable production in the European Union [35]. Vegetable production accounts for less than $1 \%$ of the United States crop area, but $14 \%$ of its total pesticide use [36]. Insecticides are regularly applied to control a complex of insect pests that cause damage by feeding directly on the plant or by transmitting pathogens, particularly viruses. Despite pesticide use, insects, pathogens, and weeds continue to cause a heavy toll on world vegetable production. Pre-harvest losses are globally estimated as $15 \%$ for insect pests, $13 \%$ for damage by pathogens, and about $12 \%$ for weeds [37].

Studies on pesticide levels in vegetables, in some developing and developed countries, found that the pesticide residues sometimes exceeded tolerance limits [38]. For example, in India a survey of pesticide residues in vegetable crops taken at the farm gate and in markets from 1999 to 2003 confirmed that of the 3,043 samples, two-thirds were found to have pesticide residues and 9\% contained residues above the maximum residue levels (MRLs) [39]. The increase of residues in vegetables is a major concern to consumers and there are some concerns about the ability of small growers to meet exacting quality and safety standards of the commercial sector. The problem of residues is not restricted to developing countries. In Europe, a recent survey of pesticide residues in vegetable and fruit crops taken by the EU coordinate pesticide monitoring programme in 2008, carried out in 27 EU member states and two EFTA states (Norway and Iceland), and analysing 78 pesticides, confirmed that $21.2 \%$ of the samples have measurable residues and from the 58,784 of samples analised, $3.7 \%$ exceeded the MRLs [40]. In USA, about 35\% of the food purchase by American consumers, have detectable levels of pesticide residues, and $1 \%$ to $3 \%$ of these foods have pesticide residue that are above the MRLs. Residue levels may be higher because the analytical methods now employed in the US detect only about one-third of the more than 800 pesticides in use on crops [41].

Pesticide residues are often attributed to the failure of growers to restrain application before harvesting and the use of prohibited pesticides. Residues affect the health of growers and consumers and contaminate the environment Also the presence of pesticide residues may restrict trade opportunities. In South Asia, pest and disease vectors of eggplant, tomato and legumes, notably eggplant fruit and shoot borer, cotton bollworm, root knot nematode, white fly, and legume pod-borer have been identified as the major targets of pesticide use and abuse with frequent and excessive applications of pesticide. However, eggplant fruit and shoot borer pheromone traps and net houses developed by AVRDC (The World Vegetable Center) have helped reduce pesticide application significantly. The promotion of integrated and biological pest control is expanding worldwide. The use of improved vegetable cultivars with resistance or tolerance to diseases and pests can also contribute to the reduction of pesticide applications and pesticide residues [12].

Genetically Modified Crops (GMOs) are now widely used in a number of countries for the production of largescale agronomic crops, especially maize, soybean and canola (oil seed rape). This is, however, not the case for vegetables crops where concerns and debates about the safety and the wider justification of genetic modification prevail in many countries [42]. Of concern, is the lack of awareness about the role that conventional plant breeding plays in the production of new cultivars and the confusion that often prevails between conventional breeding and plants produced using gene transfer technologies. The changes outlined above are merely some of the factors that are impacting on current production practices for horticultural crops. They also provide a plethora of opportunities for horticultural science to solve many of the current problems facing producers and to offer solutions to those issues that are concerning consumers [42-44].

Along with potentially toxic pesticide residues, vegetables grown on polluted soils and in the vicinity of rail, 
roads and industrial areas can be contaminated with heavy metals (mostly lead), sulphur and nitrates. These toxicants affect the nervous, digestive and circulatory systems, particularly threatening the health of young children. Fundamental factors determining the presence of these metals and toxicants in vegetables are the distance of the production area from the source of pollution and the duration of exposure to the toxicants. Also the type of vegetable grown determines the potential contamination. In general, leafy vegetables and vegetables with longer growing period are the most sensitive. Several surveys on quality of soils and vegetable production show that that, all over the world, large areas of vegetable production are polluted.

Nitrate is formed from fertilizers, decaying plants, manure and other organic residues. Due to the increased use of synthetic nitrogen fertilizers and livestock manure in intensive vegetable production, vegetables and drinking water may contain higher concentrations of nitrate than in the past. The presence of nitrate in vegetables, as in water, is a serious threat to man's health. Nitrate per se is relatively non-toxic, but approximately $5 \%$ of all ingested nitrate is converted in saliva and the gastrointestinal tract to the more toxic nitrite. The only chronic toxic effects of nitrate are those resulting from the nitrite formed by its reduction by bacterial enzymes. Nitrite and $\mathrm{N}$-nitroso compounds, which form when nitrite binds to other substances before or after ingestion (for example, the amines derived from proteins), are toxic and can lead to severe pathologies in humans. Thus, the assessment of the health risk of nitrate to humans should encompass the toxicity of both nitrite and N-nitroso compounds.

The accumulation of nitrates in the environment occurs also quite easily by vegetable production activities, mainly by the unpropriate use of nitrogen fertilizers, and affect particularly bodies of water such as groundwater. Excessive nitrogen applications are very commom in China due to rising population which requires increase vegetables supply, resulting in greater production of nitrate-rich runoff from vegetable crops grown. In Beijing, nitrogen fertilizer use has been steadily increasing from $263 \mathrm{~kg} / \mathrm{ha}$ in 1991 to $344 \mathrm{Kg} / \mathrm{ha}$ in 2001. An extensive survey in Beijing during 1996-2000 period found: i) excessive nitrogen applications with up to five times required rates of nitrogen; ii) 78\% of farms using 300-900 $\mathrm{kg} / \mathrm{ha}$ on Chinese cabbage; iii) $35 \%$ of greenhouse tomatoes receiving more than $1000 \mathrm{Kg} \mathrm{N} / \mathrm{ha}$ [45]. The consequences of these practices are that nearly $50 \%$ of nitrogen fertilizers leach into the soil and groundwater instead of being utilized by vegetable crops. As referred above it is known that high intake of nitrates from vegetables present potential adverse health implications. Vegetables grown and irrigated by water from these sources tend to accumulate a considerable amount of nitrates, mostly from fertilizers. Eighty percent of rural people and 50\% of urban people in India rely on groundwater for drinking and for vegetable production. Nitrate concentration are over the permissible limit of 45 ppm in 11 Indian states covering 95 districts. A study on water quality in vegetable production areas in northern China showed that nitrate pollution in ground and drinking water has become a serious problem [46]. Nitrate contents exceeded the limit of $50 \mathrm{ppm}$ for drinking water in over half of the 69 sites investigated, and in the worst case the nitrate content of groundwater reached up to $300 \mathrm{ppm}$. In all sites surveyed high amounts of nitrogen fertilizer were applied: recorded rates reached up to $1900 \mathrm{Kg} /$ ha per year. Similar levels of nitrogen fertilizer input and emissions were observed in vegetable production in eastern and southern China [47]. Generally, nitrate accumulating vegetables are leafy and root Brassicaceae (Chinese cabbages, leafy oriental vegetables, cabbages, rocket, turnipgreens, cress, radish, kohlrabi), Chenopodiaceae (spinach, beetroot and Swiss chard), Asteraceae (lettuce, leaf chicory and escarola) and Apiaceae (parsley, celery, celeriac, carrot and fennel) $[9,48]$. Some of these vegetables are amongst the most highly consumed throughout the year in many regions of the world. Growers should then adhered to good practice of utilization of nitrogen fertilizers.

\section{VEGETABLE TRADING}

Globalization has also now become increasingly important among vegetable producers as indicated by the recent massive increases in international trade of fresh and lightly processed vegetable crops. As a result of the increased frequency of world travel, there is a substantially greater variety of vegetable crops available worldwide in many local markets. Worldwide, the total volume traded in vegetables has increased fivefold from 1965 to 2005 [24]. The European Union (EU), followed by North America and Japan, are the world's most important fresh vegetable import regions. A large share of this comes from Africa, Latin America and the Caribbean , and from China, each contributing roughly one-tenth to overall vegetable exports. While more than $75 \%$ of global vegetable production takes place in Asia and in the Oceania, only about $12 \%$ of the total value of exported horticultural products is generated in Asia and in the Oceania regions [24]. Because of the large share that Asia and the Oceania has in global population, domestic markets and their requirements are likely to continue to be more important in the near future than the attraction of export markets. In Asia, China, Thailand and the Philippines are the largest net exporters of vegetables, while Singapore, the Republic of Korea, and Malaysia are the largest net importers of vegetables [24]. In sub-Saharan Africa, Kenya and Côte d'Ivoire are two of the most important vegetable producers for export. 
While many other agricultural commodities face stagnation and declining world prices, vegetable exports have grown dramatically. In many African countries, export of fresh vegetables has become a bright spot in an otherwise dim agrarian landscape [49,50]. There are several reasons for the rapid increase in vegetable trade over the past decade. In the 1990s, many countries, particularly in Africa and Latin America, changed their trade policies from protectionist to more openness, economic liberalization, and export diversification. This opened the way for several new trade agreements that facilitated trade in high-value agricultural products, such as vegetables. For example, liberalization under the North American Free Trade Agreement (NAFTA) underpinned the rapid growth in United States of agricultural imports from Canada and Mexico [51]. In the European Union, horticultural products have also benefited from preferential trade access. For instance, imports of fresh vegetables into the European Union rose by $150 \%$ during 1989-1997, with almost three-quarters of the value of these exports coming from sub-Saharan Africa. The majority of exports come from countries with preferred trade status under the Lomé Convention. For instance, in 2000, Kenya was the single largest supplier of green beans to the European Union, followed by Ethiopia, South Africa, and Switzerland. Kenya captured 53\% of the total traded value. Côte d'Ivoire was the second largest supplier of green onions and shallots to the European Union, after New Zealand, capturing $16 \%$ of the total traded value [52]. Although within this same period, many world governments have increased the levels of protectionism against imported produce or at least have slowed down the opening of their markets to increased exposure to imports.

The increase in total volume of vegetables traded worldwide has been dramatic. Still, compared to overall exports of agricultural products, the importance of vegetable exports remains minor, comprising less than $10 \%$ of the total value. However, in recent years the share has been rising and it is projected to continue to rise faster than other agricultural products. During the 1990s, the value of fresh and processed vegetables imported by the European Union surpassed all other categories [50]. Growth in these commodities is also linked to changing trends in consumer preference and food retailing. In this situation many vegetable growers are eager to produce value-added horticultural crops as compared to field crops, and to obtain higher yields of high-quality products. International supermarket chains and large processors are becoming the main buyers of exported fresh vegetables [19] and small-scale growers worldwide need to be trained and organized to meet the challenge of supplying these international players. The major constraints to the participation of small-scale growers in internation- al vegetable exports are the increased awareness that food quality and safety is receiving in the food trade and as well, an expansion in the number of non-tariff measures that developed countries apply to vegetable products [12,32].

Vegetables belong to the class of food items most frequently affected by sanitary and phytosanitary measures [53]. Sanitary issues refer to ensuring a safe food supply for consumers, while phytosanitary issues concern the protection of domestic crops from imported pests and diseases. The Sanitary and Phytosanitary Agreement (SPS) of the World Trade Organization specifies that countries can pursue their own levels of food safety standards. However SPS issues are sometimes used as a protectionist tool against imports since multilateral trade agreements have reduced the ability to protect domestic production with tariffs and quotas [54]. SPS regulations may be the most important barrier to international trade in fresh vegetables [53]. Thus exporters from less developed countries must be provided with training opportunities and information access on how to produce and supply safe products to developed countries. Traceability, phytosanitary, infrastructure, and productivity issues will continue to be a barrier for participation in the vegetable trade for most of the developing world. Application of agricultural chemicals is often poorly regulated, and industrial pollutants are common hazards in the soil, water, and air of developing countries. In the future, the inability of these countries to meet increasingly strict phytosanitary and traceability requirements for food products will constrict exports to developed countries [12]. Smallscale growers and processors in developing countries will thus have to learn to supply safe products with traceability labels, if their participation in global trade is to continue and to expand. Technologies for safe and environmentally friendly vegetable production as well as capacity building should therefore gain particular attention for training to enable small-scale growers to participate in vegetable production for international markets [12,32].

Food and nutritional security involves securing the whole food chain from production through to consumption. Horticulturists traditionally have focused on production, but issues such as equitable access to food and ensuring a balanced diet increasingly demand attention. Those with the least power and already substantially imbalanced diets are most affected by climate change and limited resources. Horticulturists need to build greater connections with health professionals who have more experience with aspects of consumption. We are all concerned by what we eat, and securing the food chain to provide a balanced diet (particularly for the most vulnerable), can point us toward an alternative way of viewing the role of horticulturists in a warming world. 
4. MEETING CONSUMER PREFERENCES THROUGHOUT THE VALUE CHAIN WITH END-USER-DRIVEN VEGETABLE BREEDING

Vegetable breeding has to address and satisfy the needs of both the consumer and the grower. The general objectives for growers are good yield, disease and pest resistance, uniformity, and abiotic stress resistance. Objectives for consumers are quality, appearance, shelf life, taste, and nutritional value. Quality in vegetable crops, in contrast to field crops, is often more important than yield. For growers to survive, cultivars must be accepted by the market. Thus, color, appearance, taste, and shape are usually more important than productivity. For example, tomatoes to be used either fresh or in processing must have distinct quality characteristics. Fresh tomatoes must have acceptable flavor, color, texture, and other taste parameters to satisfy consumer demands and handling requirements. Processing tomatoes, on the other hand, must have intrinsic rheological characteristics that make them suitable for various processing applications, such as juice, ketchup, or sauce production. Traditional breeding requires the selection of a tomato genotype or a related wild species that has a desirable trait, such as early ripening or disease resistance, and crossing it with another tomato cultivar that has a good genetic background. The desired result is an earlier ripening tomato that makes it to the market sooner, or cultivars that resist pathogen attack. In this way, several thousands of tomato cultivars have been developed over the years. The final goal of vegetable breeding programs is then to release new cultivars having elite combinations of many desirable horticultural characteristics.

Consumers (and therefore supermarkets) are seeking new eating experiences, different quality attributes and improved convenience, and are prepared to pay a premium for such produce if their expectations are met. Plant breeding for improved taste, convenience, and consumer appeal has already contributed to increased per capita vegetable consumption with the development of products such as baby carrots, yellow and orange peppers, cherry and pear tomatoes, non-bitter cucumbers, mild tasting eggplants, seedless watermelons, and lettuces with different colors, textures and flavors for baby leaf and precut salads. In some instances, these premiums are considerable and bring benefit to the overall vegetable industry through improving the popularity of the vegetable crop overall. Further, the premiums achieved can exceed those that consumers are prepared to pay for the choice of consuming organic produce.

Other important objectives of vegetable breeding are disease and pest resistances. Since the early days of the 20th century, traditional breeding for disease resistance in vegetables has been a major method for controlling plant diseases. Cultivars that are resistant or tolerant to one or a few specific pathogens are already available for many vegetable crops. Resistant hybrids with multiple resistances to several pathogens exist and are currently used in vegetable production. For example, in tomato, the genetic control of pathogens is a very useful practice and most resistances are monogenic and dominant. So far, tomato breeding has resulted in cultivars with resistance to at least 15 pathogens, although with varying stability and level of expression [55]. Tomato cultivars with some resistance to fungi or oomycetes (Alternaria alternata f. sp. lycopersici, Cladosporium fulvum, Fusarium oxysporum f. sp. lycopersici, Fusarium oxysporum f. sp. radicis-lycopersici, Phytophthora infestans, Pyrenochaeta lycopersici, Verticillium dahliae), bacteria (Corynebacterium michiganense, Pseudomonas solanacearum, Pseudomonas syringae pv. tomato), virus (beet curly top hybrigeminivirus, tomato mottle bigeminivirus, tomato spotted wilt tospovirus, and several variants of the tomato yellow leaf curl bigeminivirus), and nematodes ( $\mathrm{Me}$ loidogyne spp.) are available [56]. Many open-pollinated cultivars of tomato presently cultivated possess genetic resistance to three or four pathogens. With the increasing use of F1 hybrids it is possible to use cultivars combining from four up to six resistances [55].

Pest resistance is essential in vegetable production but is marginal in vegetable breeding research. There are few vegetable cultivars resistant to insects. Resistance may be unstable due to genetic variants of the insect that are able to overcome that source of resistance. Depending on the complexity of the interaction between the pest and the vegetable plant, plant resistance may break down rapidly or be long-lived. Insects, including aphids, whiteflies, thrips and leafhoppers, are also very important in vegetables because they vector many viruses. Viruses can substantially reduce production and quality and are becoming increasingly problematic worldwide due to the absence of virus resistant germplasm for many important vegetable crops. Aphid vectored viruses are particularly problematic because many are transmitted in a non-circulative and non-persistent manner $[57,58]$. This means that a very short time, i.e. a few seconds or minutes, is sufficient for aphids to acquire virus particles when probing on infected plants. A similarly short time period is enough for aphids to release virus particles when probing on healthy plants. The primary injury caused by aphid-vectored viruses arises not from direct feeding damage by the aphids, but from their ability to allow the virus to enter the plant and initiate the disease. A successful application of biotechnology has been the development of vegetable cultivars that resist insect transmitted viruses, as well as cultivars that directly resist insect feeding or development. Bt potato cultivars expressing 
resistance to Colorado potato beetle (Leptinotarsa decemlineata), and aphids associated with potato virus $\mathrm{Y}$, and potato leaf roll virus, were approved for sale in the United States in 1995. These cultivars were marketed and sold under the trade name NewLeaf ${ }^{\circledR}$, NewLeafY ${ }^{\circledR}$, and NewLeafPlus $^{\circledR}$ [59], until potato processors, concerned about consumer resistance and loss of market share in Europe and Japan, suspended contracts for $B t$ potatoes with growers in 2000 [60]. Because of this consumer concern $B t$ potato cultivars were taken off the market in 2000. Two other $B t$ vegetable crops are under development: Bt eggplant targeted for control of eggplant fruit and shoot borer, and $B t$ crucifer vegetables targeted against diamondback moth $[42,44]$.

The economic return of investment in breeding for disease and pest resistance may be low because it is dispersed among many different vegetable crop types. Also resistant cultivars compete directly with non-resistant ones that may still be used by growers with minimum problems. Therefore disease resistance is most important when the disease is a limiting factor in production, and is especially important for many virus diseases. The high interest in, and the increasing present demand for breeding for disease and pest resistance is related to a generalized interest in releasing "environmentally friendly" vegetable cultivars requiring sparse or no use of pesticides.

Breeding for postharvest traits, mainly transport quality, shelf life and cosmetic problems, is of increasing importance in vegetables. For example, in tomato, textural properties of fruits are important contributors to the overall quality for the fresh market and to the properties of products processed from tomatoes [61]. Because cell wall disassembly in ripening fruit contributes to fruit texture, modification of cell wall proteins and enzymatic activity during ripening can impact cell wall polysaccharide metabolism and influence texture. Lettuce and other leafy vegetables used for salads deteriorate rapidly following harvest, requiring a considerable investment of effort to maintain quality and shelf life of cut material. Harvesting increases respiration, stimulating deterioration, with increase in the synthesis of phenylalanine ammonia lyase and phenolic compounds, such as chlorogenic acid which cause tissue browning [62]. Consequently, delaying leaf senescence is an important target for breeding of leafy vegetables. Also in lettuce, breeding efforts have targeted tipburn, marginal browning, and rib discoloration, which detract from overall appearance [63]. Vegetable products with good transport quality, better shelf life and good appearance will be preferred by traders and also by consumers.

Since vegetables are rich in vitamins, minerals and other micronutrients, and therefore vital for health, breeding objectives should include improving their nutritional value. Historically vegetable breeders have applied selection pressure to traits related to agronomic performance, particularly yield and quality, because these are the traits important to the producer. Rarely have growers been paid for nutritional factors, so there have not been economic incentives to pay much attention to these traits. However, consumers are becoming more aware of these traits [7].

Vegetable breeding for nutritional quality was not mentioned as a primary goal in plant breeding text books through the mid-20 ${ }^{\text {th }}$ century (e.g. [64-66]). However vegetable breeding efforts targeting improved micronutrient content and composition had begun in the 1940s and 1950s with research describing the inheritance and development of tomato breeding stocks and lines high in provitamin A carotenoids and vitamin C [67-69]. Lincoln et al. [67] noted a fourfold variation in vitamin $\mathrm{C}$ among commercial cultivars and up to $1194 \mathrm{ppm}$ in red-fruited tomato interspecific crosses with Solanum pimpinellifolium. Similar research leading to the development of darker orange, and consequently high provitamin A, carrots began in the 1970s [70]. Yellow core color occurs only in older open-pollinated carrot cultivars since uniform orange storage root color has been a trait of interest in carrot for over a century [71]. Similar studies were made in squash where rapid gains in carotenoid content have been made with phenotypic selection for orange color versus green and cream [72]. Genetic improvement to increase levels of specific micronutrients has been pursued in several other vegetables such as melon, spinach, sweetpotato, potato, lettuce, broccoli, pepper, watermelon, collard, kale, peas, and bean. This field of study is relatively new, and also complex because of mineral interactions with each other, and numerous other compounds in the soil and in the plant [73]. There is usually a large environmental effect, when the component is present in tiny amounts, such as for some micronutrients and phytochemicals. Success in vegetable breeding for higher vitamin and mineral content must consider not only substance concentration but also organic components in plants that can be abundant and either reduce or increase bioavailability [73].

With these numerous considerations, breeding vegetable plants for improved nutritional value is a complicated goal that needs expertise in many disciplines such as plant breeding, nutrition, and soil science. When a vegetable compound (micronutrient or phytochemical) is found to be important for human health, and growers, vegetable markets and seed companies can capitalize on the value of the compound, there may be an opportunity for vegetable breeders to increase the amount of this compound. Breeders can be successful in reaching this goal, if the vegetable crop contains genetic variability for the compound, if selection is effective without detrimental pleiotropic effects, and if there is an easy method to measure the compound. 
Enhanced nutritional content would add value for poor, malnourished populations. Breeding for provitamin A carotenoids, iron, and zinc is of keen interest as a strategy to alleviate nutrient deficiencies in developing countries $[7,74]$. An example is the "golden tomato" which contains three to six times more provitamin A carotenoids than standard tomatoes. Developed at AVRDC with conventional breeding techniques, these improved nutritionally-rich tomato lines could help prevent many children of developing countries from going blind, since vegetarians and populations with limited access to animal products depend on provitamin A carotenoids for vitamin A. One "golden tomato" can provide a person's full daily vitamin A requirements. Tomato fruit and its processed products are the principal dietary sources of carotenoids such as lycopene. Lycopene is a potent antioxidant with the potential to prevent epithelial cancers and improve general human health. Therefore, there is considerable interest in elevating the levels of carotenoids in tomato fruit and thereby improve the nutritional quality of the crop $[75,76]$. The B gene from Solanum hirsutum shifts tomato carotenoid accumulation from lycopene almost entirely to $\beta$-carotene and results in orange fruit color [77]. This consequently dramatically increases the provitamin A carotenoid content. $\beta$-carotene content of commercial cultivars, as mentioned, is of interest [78], and several high $\beta$-carotene orange cherry tomato breeding lines have been bred [79]. Rainbow carrots, which are super sweet and crunchy, have multi-pigmented roots that naturally contain several antioxidants, such as lycopene, lutein, and anthocyanin. Similarly, yellow sweet potatoes are much more nutritious than white ones since they are high in provitamin A carotenoids. Unfortunately, the popularity of white fleshed sweet potato cultivars in many tropical regions may complicate the acceptance of more nutritious orange ones. Recent studies across a range of Andean potato cultivars show wide variation in calcium, iron and zinc content [80] as well as anthocyanins [81,82] due to the existence of red-, blue- and purple-fleshed potatoes.

A vegetable, in order to have impact for its nutrient content, must be appealing to consumers. Sensory appeal, including color, is an attribute important to consumers when selecting many vegetables. Enhanced pigmentation of carrot, potato, tomato, and pepper, for example, is considered a quality factor $[70,82]$. In peppers carotenoid content of green, yellow, orange and particularly red peppers can be relatively high. Selection for high pigment is an important goal because these carotenoids are important for visual appeal in many markets but until now didn't have any specific nutritional impact $[7,83]$. In the past yellow or orange tomatoes could not compete with red tomatoes because they were unfamiliar to consumers, but now they are commercialized, and are challenging the market. This fact and recent development of orange colored cauliflower [84] and orange flesh cucumbers [85] reflect a new direction in vegetable breeding: nutritional quality. The white versions of these two vegetables lack carotenoids present in high enough concentration to alter their appearance. As nutritional quality becomes a more common breeding goal, and the novelty of unusual colors brings added value to seed companies and vegetable growers, unusual colors will quite certainly become more available and perhaps more widely consumed. But consumer requirements for quality: appearance, shelf life, and taste, must be met. Breeding to increase consumer appeal by improving convenience and the quality factors of a moderately nutritious crop often can be a more effective approach to increase intake of shortfall nutrients [86]. Nutritional quality identifiable by the consumer and available at a moderate price might induce increased consumption and thus confer an important marketing incentive for breeding activity.

Vegetables generally are sensitive to environmental extremes. High temperatures and moisture stress are already major causes of low yields in the tropics and these are likely to be exacerbated by climate change. Vegetable crops of predominantly temperate origin that are popular in the Western countries have come to dominate world production, aided by their spread to all continents during colonial times. Far less emphasis has been placed on tropical indigenous vegetables from Asia and Africa that in many cases may be better adapted to future warmer climate scenarios than the vegetable crops the world more commonly views. Most vegetables prefer cooler temperatures, and productivity is lowest in the hot and humid lowlands. Vegetable breeders need to rethink which vegetables a warmer world will need to rely on. High value vegetables preferentially receive more inputs than other vegetable crops to help them cope with unfavorable weather and nutritional deficiencies, but extremes of heat, drought, salinity, and flooding will be unavoidable in a warming world. Some vegetable cultural practices to cope with these stressors already exist, but the development of well adapted cultivars will take longer. Little work has been done to assess the genetic variability of most vegetables to cope with less than optimum growing conditions.

Improved production systems that can cope with climate extremes must allow vegetables to produce under high temperatures, greater drought stress, increased soil salinity, and periodic flooding. This will involve a combination of improved cultivars and modified production systems. Most research on the effect of environmental stress has been done on tomato and there is a great need for more research on other vegetables [87]. High temperatures decrease pollen productivity and viability [88], and inhibit photosynthesis in tomato [89] resulting in reduced fruit set, smaller and lower quality fruits, and ultimately a reduction in yield. Drought is the single biggest cause of crop failures worldwide [90] and vege- 
tables are particularly susceptible as most are succulent plants consisting of generally more than $90 \%$ water [91]. Soil salinity is an increasing threat; high soil salinity afflicts about $20 \%$ of cultivated land and 33\% of irrigated land worldwide [92]. Many globally important vegetables, including onion, are sensitive to soil salinity while cucumbers, eggplants, crucifers, peppers and tomatoes are only moderately sensitive [93]. Vegetable production in the tropics is often limited during the rainy season as most vegetables are highly susceptible to flooding. Genetic variation in this characteristic is limited, particularly in tomatoes, which rapidly wilt and die following a short period of flooding, particularly at high temperatures [94].

Breeding vegetables for heat tolerance has proved easier than breeding for drought, salinity, or flooding tolerance [87]. AVRDC has developed cultivars of tomato and Chinese cabbage with good adaptation to hot and humid tropical environments since the early 1970s. These improved lines initiated the successful cultivation of tomato and Chinese cabbage in the lowland tropics. The heat tolerant lines of tomato show no reduction in pollen viability from heat stress and produce a fruit set $15 \%$ higher than heat sensitive cultivars under the same conditions. More improved lines are needed for future climatic scenarios, and these must be able to match the yields of conventional cultivars under favorable growing conditions.

New cultivars must be developed from both existing tomato lines and from the relatively unexploited wild relatives of tomato. It is particularly challenging to breed for drought and salinity tolerance as this is controlled by multiple genes. It also varies with crop developmental stage [95]. Some wild relatives of tomato have good drought and salinity tolerance [96], but this is often genetically linked to undesirable fruit characteristics such as small fruit size and low fruit set and yield.

Developing vegetables that are more tolerant of environmental extremes should not be limited to only those of global importance. Many indigenous landrace vegetables from the tropics already are well adapted to the climatic conditions likely to be more widespread in the future. Many are highly nutritious and familiar to smallholder farmers, and can provide excellent opportunities to help farmers cope with climate change.

\section{GUIDELINES AND PRIORITIES FOR RESEARCH ON BREEDING AND PRODUCTION OF VEGETABLES}

\subsection{Seed Breeding Industry}

In the case of most vegetable crops, biodiversity and genetics are delivered in a marvelous package known as the seed. The special techniques of seed production, such as seed treatment for the control of planting diseases and viruses, and the combination of breeding improvement program such as development of hybrids and the incorporation of biotechnology, cannot be efficiently carried by individual growers. By these reasons in modern vegetable production the seed business is usually conducted as a distinct industry. High tech seed industry is a key part of modern horticulture that combines, seed production, genetic improvement, seed production, storage, and distribution. One of the main factors that determine success in vegetable production is biodiversity and genetic capacity. No practical breeding program can succeed without large numbers of lines (genotypes) to evaluate, select, recombine, and inbreed (fix genetically). This effort must be organized, so valid conclusions can be reached and decisions made. Scientists, breeders, support people, and facilities, budgets, and good management are requirements to assure success in the vegetable seed business. Science must be state of the art to maximize success in a competitive business environment. Since the continued need for fundamental breeding research is critical to sustain development of new technology and expansion of the knowledge base that supports cultivar development, competition among proprietary cultivars results in owner-companies striving to do the best possible research to develop their own products and to compete on genetic and physiological quality of vegetable seed in the marketplace. Reasonable profit margins are necessary to pay back the R\&D costs to the owner and to fund future research on developing even better vegetable cultivars to stay competitive [97]. There is considerable genetic variation within the various vegetable species, which can be exploited in the development of superior proprietary cultivars. The consequences of this dynamic situation mean that relatively short-lived cultivars are replaced by either the owner of the cultivar or a competitor seed company. This intense competition means constantly improved and more sophisticated cultivars for the vegetable industry. Seed companies are in the business of manipulating genes to improve plant cultivar performance for a profit. The success of the research is judged by the success of the product in making a reasonable profit. The research must improve economic performance starting with the seed production costs and include the grower-shipper/processor and the end user. If any link in this sequence of events is weak or broken, the new cultivar likely will fail $[97,98]$.

Private breeding companies are placing more and more emphasis on the development of hybrids to exploit heterosis, and to combine multiple disease and stress resistance, but also for economic purposes to ensure growers must purchase seed for each planting. Control of the parents prevents other seed companies from reproducing the hybrid. 
Farmers pay all the breeding work and seed marketing costs when purchasing improved or hybrid vegetable seed. International seed companies are mainly interested in the breeding and production of vegetable seeds with a high commercial value. Traditional vegetable landraces have largely been neglected by seed companies, policymakers, and researchers. But while their production often takes place under low-input conditions, they contribute substantially to household food and livelihood security, particularly for small resource-poor farmers [99,100]. For example, in Africa traditional landraces constitute an important source of micronutrients, contributing between $30 \%$ and $50 \%$ of iron and vitamin A consumed, respectively, in poor households [100,101].

Breeding companies strived more and more to bring hybrid seeds onto the market. Worldwide the share of hybrid seed is increasing at a fast pace of $8 \%-10 \%$ annually in most of the vegetables. More than two-thirds of the 5000 non-hybrid vegetable cultivars available in 1984 seed catalogs from North America were dropped during last 25 years [12,98].

Hybrid vegetable technology has made significant impact on most vegetable crops in developed countries, but a major limitation to vegetable production in many developing countries is the unavailability of high quality seeds. Hybrid seed production is a high level technology and cost intensive venture. Only well organized seed companies with good scientific manpower and wellequipped research facilities can afford hybrid seed production. The public sector in developing countries frequently does not have sufficient capacity to supply adequate quantities of good quality vegetable seed to poor farmers and at present, there are few private sector seed companies adapting cultivars to local environments, especially in the poorer countries [97,98,102]. Farmers themselves often produce seeds of locally preferred or traditional landraces, as the individual markets are too small and private companies have little interest in producing open pollinated cultivars $[12,100]$. Without proper seed production, processing technology, quality assurance, and management supervision, locally produced seeds are often contaminated by seed transmitted viruses and other disease organisms, and are genetically diverse. Lack of proper storage facilities and an effective monitoring mechanism often leads to low or uncertain seed viability and vigor. Moreover, low capital resources and poor market information discourage the development of seed-related agribusinesses. Seed quality and treatment are keys to product quality, and there is a need for upgrading quality control laboratories to meet international standards. By those reasons in modern vegetable production the seed business is usually conducted as a distinct industry $[12,97,98]$.

The global seed trade is now dominated by interna- tional corporations whose vast economic power has effectively marginalized the roles of public sector plant breeding and local, small scale seed companies. Thirty years ago there were thousands of seed companies in the world, most of which were small and family owned. Today, the top six global seed companies control almost 50\% of the commercial seed trade $[97,98]$. Some of these companies belong to worldwide corporations that are also involved with pesticides and biotechnology. The vegetables attracting the most breeding attention vary considerably between small and huge seed companies/ corporations. Small seed companies have a tendency to specialize in a few vegetable crops. In large international companies the breeding activity is more diverse, but is concentrated on the more economically important crops. In these companies, marker assisted selection (MAS) has become an integral component of many commercial vegetable breeding programs [103,104]. The initial aim of molecular breeding has been to supplement conventional methods with faster and more efficient breeding through MAS or marker-assisted backcrossing (MABC). Molecular markers that are closely linked to the trait of interest may be identified and applied in gene pyramiding, facilitating introgression of desirable traits into cultivars, early selection, etc. For more complex traits conferred by multi-genic traits, QTL analysis has been carried out. Markers bring additional value when they can be used to accelerate the development of new improved vegetable cultivars. Developmental cycles of commercial hybrid cultivars range between 5 and 12 years. Besides breeding lines necessary for creating hybrid seed need to be refined for specific markets. All these high significant R\&D investments make commercial vegetable breeding expensive.

A greater desire for year-round availability of vegetables has had a significant impact on seed companies, requiring full year-round production and consequently a global presence. Unlike for instance agrochemicals "where one size fits all", seed cultivars need to be adapted and differentiated to suit the agronomic needs of the respective region where the vegetable is grown. Active international trade and overseas vegetable seed production by contract is common in many countries. Each multinational company vies to provide better vegetable seeds to compete with domestic seed producers. In China, whose seed market is estimated to be valued at more than US $\$ 1.4$ billion, the increased recognition of new and high-yielding hybrid cultivars has encouraged the local development of a large number of vegetable seed producers and distributors. Four types of vegetable seed producers were established: public seed companies, research institutes, foreign seed companies, and local seed companies. Private seed companies have been expanding rapidly in recent years and there are now thousands of 
small firms. Some companies have started to breed their own cultivars and establish marketing networks. They play a strong role in the Chinese vegetable seed industry. About 60 foreign seed companies have opened branch companies or stations in China. Most of them not only sell their vegetable seeds but also have established breeding stations. In other southeastern Asian countries such as India, Indonesia, Vietnam and Malaysia, the percentage of hybrid vegetable cultivars is lower than in China, and so a large expansion of seed companies has not yet occurred. While there has been rapid growth in the seed markets of developing countries due to a shift away from farm saved seed, the seed markets in developed countries, particularly those of Europe and Japan are stagnant. In Europe and the United States, the seed industry has been concentrated and is largely in the hands of large corporations and many small firms are closing [12,97,98].

Vegetable breeding strategy and targets are dependent on market trends. Successful breeders anticipate changes in the market by developing new cultivars that are ready to be released to the growers when their demand increases. Therefore, it will be interesting to see how breeding companies react to changes in vegetable consumption and to evaluate the potential influence that the vegetable market and growing systems may have on breeding targets and priorities.

\subsection{Biodiversity and Germplasm Conservation}

As stated biodiversity is the basis for plant breeding. Selection is impossible without diversity and new cultivars for farmers and growers cannot be developed without it. This makes access to this variation essential for breeders.

As referred above, about one half (52\%) of the total number of vegetables cultivated in the world get commercial breeding attention by seed companies and, of those, only $17 \%$ are in large scale breeding programs, fostering a need for serious attention to maintenance of vegetable crop biodiversity. There has been a severe decline in the vegetable cultivar genetic base, as evidenced by the significant reduction, especially within the last 50 years, in the number and range of vegetable cultivars grown. During this period vegetable genetic diversity has been eroding all over the world and vegetable genetic resources are disappearing, on a global scale, at an unprecedented rate of $1.5 \%$ - 2\% per annum [97,98,102]. Widespread adoption of simplified vegetable systems with low genetic diversity carries a variety of risks including food insecurity. In the short term, such systems risk potential crop failure. In the longer term, they encourage the reduction of the broad genetic base that contributes to high yields, quality traits, disease and pest resistance, etc. and thus compromise the future genetic health of vegetables.

Especially prominent among the "enemies" of genetic diversity are the commercial markets and economic social pressures that have influenced breeding practices that promote uniformity, encouraging extensive cultivation of preferred improved and hybrid vegetable cultivars with insufficient diversity. In addition, globalization has stimulated the consolidation of vegetable seed companies into huge corporations and the decline of small seed companies that serve local and regional markets. In consequence some vegetable breeding programs have been merged or eliminated to reduce costs. Thus, fewer and fewer companies/corporations are making critical decisions about the vegetable research agenda, and the future of vegetables worldwide. Inevitably, two things will happen. There will be fewer vegetable breeders in the future and growers will be dependent on a narrower genetic background that could contribute in the near future to food insecurity for poor growers and consumers. Also, with the advent of genetic engineering, these huge seed corporations are also assuming ownership of a vast array of living organisms and biological processes. Of equal concern are expanded uses of legal mechanisms, such as patents and plant breeder's rights that are removing vegetable plant germplasm from general public use [102, 105-107]. Intellectual property rights for plants was intended as a defensive mechanism to prevent the loss of invented cultivars to competitors. However, with the more stringent enforcement of plant breeding rights, and particularly with the application of the utility patent law in the United States to protect all forms of an innovation, this has become an offensive weapon to stifle competition and inhibit the flow of germplasm and information. This can have serious implications for the future conservation of vegetable genetic resources and for world food security [102,106,107].

Some landraces and old open-pollinated cultivars of vegetables have existed for long periods outside the commercial and professional plant breeding circles because they have been kept alive within communities by succeeding generations of seed savers. Unfortunately, active seed savers tend to be more and more a minority among the millions of vegetable growers. Due to the demand of commercial markets and the professionalization of the sector, many growers are no longer saving seeds. This is an additional threat to genetic diversity. So continued survival of landraces and open-pollinated cultivars of vegetables depends largely on popular interest and initiative as well as preservation in gene banks. We should be alerted and concerned about the loss of biodiversity in vegetables and about this impact on food security.

Vegetable growers have an important role in conserv- 
ing and using vegetable biodiversity. The future of world food security depends not just on stored vegetable genes, but also on the people who use and maintain crop genetic diversity on a daily basis. In the long run, the conservation of plant genetic diversity depends not only on a small number of institutional plant breeders and seed banks, but also on the vast number of growers who select, improve, and use vegetable diversity, especially in marginal farming environments. That is why we should be also alerted and particularly alarmed by the current trend to use improved and hybrid vegetable cultivars exclusively.

Growers do not just save seeds, they are plant breeders who are constantly adapting their vegetable crops to specific farming conditions and needs. For over 300 vegetable generations, vegetable growers have been selecting seeds and adapting their plants for local use. This genetic biodiversity is the key to maintaining and improving the world's food security and nutrition. No plant breeder or genetic engineer starts from scratch when developing a new cultivar of tomato, pepper, cabbage or lettuce. They are building on the accumulated success of generations of growers, who have selected and improved vegetable seeds for thousands of years. If poor small-scale growers in marginal areas stop saving seeds, we will lose genetic diversity. Growers will lose the means to select and adapt vegetable crops to their unique farming conditions, which are characterized by low external inputs.

Hybrid seed technology is designed to prevent growers from saving seed from their harvest, thus forcing them to return to the commercial seed market every year. Hybrid vegetable seeds alone, and used globally, can be a dead-end to biodiversity. If growers abandon completely their traditional vegetable landraces in the process of adopting only hybrids, crop genetic diversity achieved over centuries will be lost forever. Many agronomic benefits will be lost to worldwide vegetable growers and thus to consumers. The exclusive adoption of hybrid cultivars in marginal areas may restrict the vegetable producing capacity of farmers, it will destroy biodiversity, and it may contribute in the long-term to food insecurity.

There is a growing awareness world-wide about the need to conserve plant germplasm for the use of future generations. Consequently, considerable media attention has been given to the creation of the Svalbard global seed vault and the related storage of seeds of many economically-important crops (see

http://www.croptrust.org/main). However, the lower "status" of most of vegetable crops means that they are not treated with the same degree of priority and concern. Furthermore, the fact that many vegetable crops of comercial and horticultural significance are vegetatively propagated and not seed propagated restricts the options for their conservation other than through relatively ex- pensive live plant collections. There are also considerable ongoing efforts by national governments and international organizations to preserve plant vegetable germplasm in gene banks. This is a valuable but static approach, as further evolutionary changes and improvements will not occur until the seeds are planted. It is also an activity that relies heavily on continued political stability and support, including sustained governmental funding. Active and positive connections between the private breeding sector and large-scale gene banks are required to avoid possible conflict involving breeders'rights and gene preservation.

The diversity of crop species will be promoted by the maintenance of crop gene banks by governments and non-governmental organizations, the continued use of diverse sources by plant breeders, especially in the public sector, and by the use of local cultivars and landraces by farmers.

\subsection{Vegetable Breeders}

Breeders play a key role in determining what we eat, since the plant cultivars they develop begin the dietary food chain. There are considerably fewer vegetable plant breeding positions than in field crops, and vegetable breeders are often required to be knowledgeable about a more diverse group of crops. Vegetable crops include many different crops morphotypes with great diversity within. So careful consideration must be given to the type of graduate education appropriate for preparing new vegetable breeders, as well as continuing education to keep them current and productive. Since many breeders will work on different vegetable crops during a career, how can they be prepared for inevitable change, the types of which are difficult to imagine? Who would have predicted in 1990 that a mere 20 years later, many plant genomes are sequenced and DNA-based selection methods linked with phenotypic selection and electronic data handling are becoming standard practice? Few of the vegetabe plant breeders beginning their careers two decades ago had much knowledge about and experience with DNA technology, but in order to be productive and competitive today they have had to learn about and integrate new technology and methods. There is no reason to suppose that changes will be any less dramatic for future vegetable breeders.

As with other courses of study, plant breeding graduate education must strike a balance between broad preparation and specialization. The number of vegetable breeders is small compared to other crops, therefore few if any graduate programs will be designated solely for vegetable. So too, limited number of university faculty working on vegetable crops will make it challenging to assemble a critical mass of faculty with research and teaching appointments and interest in a range of vegeta- 
ble crop areas. Some pertinent questions for preparation of vegetable breeders should include: i) what types of new positions will be available in vegetable crop breeding; ii) what level of formal education will be appropriate; iii) how should preparation differ for global careers that may be in developed and developing countries/regions; iv) what skills will be needed for success; v) what vegetable crops should graduates be knowledgeable about; vi) are there educational knowledge, experience and skills that differ for horticultural vs. other agronomic crops; vii) what is needed to prepare vegetable breeders for career changes among different vegetable crops; and viii) what continuing education should be available for practicing breeders throughout their careers.

The first step is to attract outstanding students into vegetable breeding programs with modern, exciting and relevant curricula that provide clear paths for obtaining knowledge, experience and skills needed for success in attractive jobs that are currently available in plant breeding globally. For all countries, vegetable products are critical for good nutrition, healthy living and a dynamic business sector. Development of new, genetically improved vegetable cultivars that are profitable for growers and that meet the needs of consumers will contribute to a vital, dynamic vegetable industry world-wide.

The ready supply of a wide range of affordable vegetable crops in most developed countries has led to a marked complacency about the need for ongoing R \& D vegetable breeding programs. Consequently, many governments world-wide have scaled back funding for vegetable breeding and production programs. Most research driven universities have now disbanded horticulture/ horticultural breeding departments (and often agronomy departments) and merged them into plant science/plant biology departments with a very strong focus on the molecular sciences. This erosion has been concentrated in what historically have been viewed as vital disciplines for vegetable breeding such as plant breeding, agronomy, pathology, and entomology.

Nonetheless, as indicated above, there are a basic need for research and breeding on vegetable crops given by the current consumer demands for affordability, safety and continuity of supply; increasing needs to achieve sustainable practices; and the need to deal with challenges arising from a more variable climate, the loss of productive soils through urban encroachment, and the loss of low-cost labour.

\subsection{Vegetable Sustainable Production Practices and Technology Transfer}

The concepts of sustainability of vegetable crops relate both to the use of resources, such as water and nutrients, in a manner which considers future needs, and the responsible use of compounds such as pesticides which will not compromise the quality of the environment (or the safety of the produce that is produced). Improved vegetable cultivars are also important since there are cultivars more apropriated for sustainable production. Vegetable breeding can be important for genetic enhancement of vegetables, and for an eco-friendly organic horticulture that will reduce human carbon footprints.

The most topical issue that is facing vegetable production in almost all areas of the world is the availability of water. Pressure on water resources for urban, industrial, recreational, conservation and other uses all appear to have higher priority within societies than the availability of water for vegetable crop production. Current demands on water from both river and subterranean sources are outstripping availability resulting in attention being given to water harvesting options with on-farm dams, the use of waste water and to the use of more efficient cultural practices. Research is urgently needed to resolve issues such as the development of drought tolerant vegetable crops, the management of crops under managed water deficits, dealing with increased salinity, and the use of low quality water.

Integrated crop production systems have been shown to be effective on a number of vegetable crops for reducing the number of pesticide applications and for shifting to new control compounds that have less persistence in the environment and which are of lower overall toxicity. Producers have behaved responsibly and with some urgency to ensure the adoption of new practices. GMOs cultivars can also be important for sustainable production [42,44]. Genetic engineering has the potential to address some of the most challenging biotic constraints faced by vegetables growers, which are not easily addressed through conventional plant breeding alone. Transgenic vegetable crops, enable also breeders to bring favorable genes, often inaccessible by conventional methods, into elite cultivars, improving their value considerably and offering unique opportunities for controlling insects and other pathogens [42,44].

Technology transfer from both university and government sources in many developed countries has markedly declined over the past two decades and have been replaced with a greater provision of services from the private sector. Paradoxically, the demand for information from public providers has nonetheless increased as providers of information in the private sector seek to stay abreast of the latest developments and as producers seek to secure the best advice possible. This can be very important for sustainable production and better knowledge of the vegetable producers about the cultivars available.

In developing countries, where often the provision of knowledge from both private and public sectors may be poorly developed, the demand for useful and relevant information is growing as vegetable enterprises become 
more sophisticated and often more focussed on exporting their vegetable produces. In parallel with such changes, there has been an unprecedented expansion of methods by which to transfer information-mobile phones, the internet, laptop computers, private and public networking, and so on. Equally, there is a growing expansion of the types of information that can be accessed including that from remote sensing, environmental monitoring, image analysis and others. The challenges relate not to the availability of information, but to the provision of relevant knowledge and the more effective means of transmitting the specific information that is required. Vegetable producers have rapidly adopted many of these technologies contributing for their success as farmers. The major challenge facing vegetable producers in the future will be to filter the information that is available into useful knowledge that will allow them to be more effective and efficient in their various enterprises.

\subsection{Health Promotion}

Regular consumption of a vegetable rich diet has undeniable positive effects on health since phytonutriceuticals of vegetables can protect the human body from several types of chronic diseases. The mechanism by which vegetables decrease risk of disease is complex and largely unknown. Various components of the whole food are likely to contribute to the overall health benefit. Various phytonutriceuticals with antioxidant properties may work directly by quenching free radicals or indirectly by participating in cell signaling pathways sensitive to redox balance $[1,2]$. Nutrients such as potassium contribute to blood pressure regulation. The dietary fiber content and type of different vegetables may also contribute to the overall health benefit, such as improving bowel transit, lowering cholesterol, helping manage blood glucose concentrations, and by transporting a significant amount of minerals and phytochemicals linked to the fibre matrix through the human gut [1]. Finaly, increaseing vegetables in the diet may reduce the intake of saturated fats, trans fats, and foods with higher caloric density, all of which may be related to a healthier overall diet [1].

A major activity over the past 2 - 3 decades has been the promotion of health benefits that can be gained through the consumption of various vegetables. This has been most evident from the various " 5 a Day" and similar promotional programmes to promote fruits and vegetables consumption. These activities that have been a success have not just included fresh vegetable and fruit products but have also embraced products based on juice, dried products and extracts, many of which have extensive on-label claims. The reality is that many such claims have not in fact been clinically proven and regulators are increasingly requiring label claims to either be substantiated or removed. Clearly, there is a need for considera- bly more research in this area in order to fully specify the presumed health benefits in many vegetables [1,2]. This is an exciting area of endeavour where there is a convergence of horticultural science with medical and nutritional research. Notwithstanding the need to prove many of the specific health claims that are made for many vegetable crops, the consumption of vegetables per capita in markets such as the United States of America has increased over the past 2 - 3 decades. However, consumer preferences have changed markedly during that same period with a growing pattern of interest in convenience, year-round availability and with novelty. No doubt the perceived health benefits of some of these vegetable crops have also helped to enhance consumption.

Because each vegetable contains a unique combination of phytonutriceuticals (vitamins, minerals, dietary fiber and phytochemicals), a great diversity of vegetables should be eaten to ensure that individual's diet includes a combination of phytonutriceuticals and to get all the health benefits. The availability of a large diversity of vegetables year-round, allied to increase in mean per capita incomes in recent years and knowledge of vegetable health benefits, have enable consumers to include a variety of health promoting phytonutriceuticals in their diet $[1,2]$.

Nutritional quality as understood by the consumers and available at a moderate price may encourage enhanced consumption, thereby conferring an important marketing incentive to vegetable plant breeding. Research on the health benefits of vegetables, from a horticultural and breeding perspective, needs to focus on key areas in the near future such as: i) to continue the evaluation of phytonutriceuticals content among older versus newer major cultivars; ii) to identify the genetic mecanisms that regulate the syntesis of their key phytochemicals, such as the glucosinolates, thiosulfides and flavonoids, in order to develop cultivars rich in a variety of phytochemicals and in order to ensure that a mixture of phytochemicals enters into the human diet; iii) to study the potencial change in the balance of these compounds (and their eventual synergisms or interactions); and iv) to identify the optimum conditions for mantaining these phytochemicals after harvest and processing since studies have shown that the biovailability of some of the phytochemicals increase dramatically after storage and processing and others de grade rapidly.

Genetic engineering enables vegetable breeders to incorporate desired transgenes into elite cultivars, thereby improving their value considerably. It further offers unique opportunities for improving nutritional quality and bringing other health benefits [42,43]. Many vegetable crops have been genetically modified to improve traits such as higher nutritional status or better flavour, and to reduce bitter-ness or anti-nutritional factors [42, 
43]. Transgenic vegetables can be also used for vaccine delivery. Consumers could benefit further from eating more nutritious transgenic vegetables, e.g. an increase of crop carotenoids by metabolic sink manipulation through genetic engineering appears feasible in some vegetables $[42,43]$. Genetically engineering carrots containing increase Ca levels may boost Ca uptake, thereby reducing the incidence of $\mathrm{Ca}$ deficiencies such as osteoporosis. Fortified transgenic lettuce with zinc will overcome the deficiency of this micronutrient that severely impairs organ function. Folates deficiency, which is regarded as a global health problem, can also be overcome with transgenic tomatoes with folate levels that provide a complete adult daily requirement. Transgenic lettuce with improved tocopherol and resvera-trol composition may prevent coronary disease and arteriosclerosis and can contribute to cancer chemopreventative ac-tivity. Food safety and health benefits can also be enhanced through transgenic approaches, e.g. rural African re-source-poor consumers will benefit eating cyanide-free cultivars of cassava. Biotechnology-derived vegetable crops will succeed if clear advantages and safety are demonstrated to both growers and consumers.

\subsection{Improved Post-Harvest and Supply Chain Methods}

A major trend over the past decade, possibly as a consequence of smaller households and more dedication to leisure activities, has been the shift towards the consumption of fresh rather than frozen vegetables. Modern consumers do not store vegetable products for long periods within the household and are able to discern the difference in quality (taste, flavor, and texture) between vegetables that have been stored for short versus long periods.

The challenge for breeding and horticultural science is, therefore, to refine methods for shortterm storage so that premium quality is retained rather than to focus on longer-term storage for prolonged marketing. Interestingly, this potentially transforms the approaches that can be taken for chilling sensitive vegetables where long-term storage techniques have not been routinely available. The option to provide for new approaches that can be used for quality retention during short-term storage should be an absolute priority.

Maturity at harvest is the most important determinant of storage-life and of final fruit-vegetable quality. Many vegetables, in particular leafy vegetables, and immature fruit-vegetables (such as cucumbers, sweet corn, green beans, peas, and okras), attain optimum eating-quality prior to reaching full maturity. This often results in delayed harvest, and consequently in produce of low quality.

The method of harvesting (hand vs mechanical) can significantly impact upon the composition and postharvest quality of vegetables. Mechanical injuries (such as bruising, surface abrasions and cuts) can accelerate loss of water and vitamin $C$ resulting in increased susceptibility to decay-causing pathogens. Most fresh vegetables are harvested by hand. Root crops (such as carrot, onion, potato, and sweet potato) and some commodities destined for processing (such as processing tomatoes) are mechanically harvested. Management of harvesting operations, whether manual or mechanical, can have a major impact on the quality of harvested vegetables. Proper management procedures include selection of optimum time to harvest in relation to product maturity and climatic conditions, training and supervision of workers, and proper implementation of effective quality control. Expedited and careful handling, immediate cooling after harvest, maintenance of optimum temperatures during transit and storage, and effective decay-control procedures are important factors in the successful post-harvest handling of vegetables. Attention must be paid to all of these factors, regardless of the method of harvesting used. These factors are nevertheless more critical in the case of mechanically harvested commodities.

It should be noted that any practice that reduces the number of produce handling steps will help minimize losses. Field packing (selection, sorting, trimming, and packaging) of produce at the time of harvest can greatly reduce the number of handling steps in preparation vegetables for marketing. Mobile field packing stations with adequate shading are used for vegetables (such as broccoli, cauliflower, and green beans) that do not require washing as part of their preparation for marketing.

Within each vegetable there is a range of genotypic variation in composition, quality, and post-harvest-life potential. Plant breeders have been successful in selecting carrot, sweet potato, and tomato cultivars with comparably high carotenoid levels and vitamin A content; onion and tomato cultivars with longer shelf-lives, sweet corn cultivars that maintain their sweetness longer after harvest; cantaloupe and watermelon cultivars with higher sugar content and firmer flesh, etc.. These are just a few examples of how genetic manipulation has contributed to improving the quality of vegetables and post-harvest potential.

Breeders have also developed vegetable cultivars with improved storage characteristics, including resistance to storage fungi and pests, as well as physiological disorders. More adequate and sustained funding for this work is required, as well as improved linkages among breeders, nutritionists, health sector experts, and policymakers. Low-cost safe storage structures for small and intermediate scale farmers need to be promoted.

Many opportunities exist for applying biotechnology to improve the post-harvest quality and safety of fresh 
vegetables. Priority goals in this regard, should, be focused on: i) attaining and maintaining good flavor and nutritional quality, so as to satisfy consumer demands; and ii) introducing resistance to physiological disorders and/or decay-causing pathogens and pests, so as to reduce the use of chemicals on vegetables. For example in tomato, the first transgenic vegetable crop, there are a lot of research conducted to manipulate fruit ripening, texture and nutritional quality using transgenic approaches. Many of the genes targeted include ethylene because of its role in fruit ripening $[42,44]$. Enzymes that regulate ethylene biosynthesis in plants are: S-adenosylmethionine (SAM) synthase, 1-aminocyclopropane-1-carboxylate (ACC) synthase, and ACC oxidase. The genes encoding these enzymes $[108,109]$ as well as those that metabolize SAM or ACC [110,111] have been targeted in order to manipulate ethylene biosynthesis, thereby regulating fruit ripening. It has been clearly shown that modulation of ethylene biosynthesis using genetic engineering can yield tomato fruits with predictable ripening characteristics. Tomato fruit ripening manipulation has been however achieved by introducing anti-ripening genes (rin and nor) in heterozygous genotypes. These genes have been incorporated in many fresh and processing tomatoes [42,44].

\subsection{Year-Round Supply}

The year-round provision of safe, nutritious vegetable crops to consumers has, over the past 50 years, primarily been through a combination of locally-produced and imported vegetable crops that have been handled through various transport and storage regimes, and shipped to both local consumers and to opposite hemispheres using such methods. The high costs of energy for transport and for storage, changes in consumer consumption preferences, and changes in consumer concerns (such as computed carbon footprints and others schemes), increasingly mean that these options may no longer be viable for some markets that want vegetables produced under a reduced carbon footprints.

Many vegetables particularly in tropical and subtropical countries have now a gross over-supply during a very concentrated production season. The aim is to extend the production season, and consequently the period available for marketing. The use of different vegetable cultivars in different seasons, and photoperiodic and vernalization sensitive cultivars for changing the flowering and therefore the production season, togheter with the use of special fertiliser and water regimes for shifting the flowering and vernalization time are effective and proven approaches that can be used for year-round supply of vegetable markets. Temperate vegetable crops can also be developed for extended production seasons as evidenced by the change in day length dependency in strawberry. Improved production using improved landrace vegetables and production under greenhouses should be also considered.

\section{OUTLOOK}

The production and marketing of vegetables crops is undergoing continuous change globally. This is mainly due to the growing demands of consumers for safe and healthy vegetables, increased urbanisation of societies, and the growth in scale and influence of supermarkets chains. The changes outlined above are merely some of the factors that are impacting on current production practices for vegetable crops. They also provide a plethora of opportunities for vegetable breeding and horticultural science to solve many of the current problems facing producers and to offer solutions to those issues that are concerning consumers. Horticultural science can respond to many of these challenges through research, breeding and innovation that can seek to gain more efficient methods of crop production, refined post-harvest storage and handling methods, newer and higher value vegetable cultivars and demonstration of their health benefits.

Horticulturists will need to develop cultural practices and vegetable breeders to breed vegetables for a multifunctional horticulture (diversity, health promotion, postharvest, year-round supply, etc.) and to cope with harsher climate conditions and lower inputs than they have come to expect. Improved production systems that can cope with climate extremes must allow vegetables to produce under high temperatures, greater drought stress, increased soil salinity, and periodic flooding. This will involve a combination of improved vegetable cultivars and modified production systems.

The continued globalisation of the vegetable industry will see a rapid transfer and adoption of knowledge. This will include the transfer from developed to developing countries as major enterprises move to year-round production and in response to securing lower-cost land and labour. Many of these activities will, however, be carried out by the private sector where the protection of intellectual property, the development of unique and proprietary vegetable cultivars and the advocacy of brands will, undoubtedly, see a markedly diminished involvement of the public sector. Modern trends indicate that consumers are seeking increased variety, novelty, and healthy options in their eating choices.

Creation of vegetable hybrids is a key means towards the development of cultivars for modern vegetable production. Hybrid seed production is high technology and a cost intensive venture. Only well organized seed companies with good scientific manpower and well equipped research facilities can afford seed production. Due to globalization most vegetable breeding research and cultivar development in the world are presently conducted 
and funded in the private sector, mainly by huge multinational seed companies. Public vegetable breeders and cultivar development activities and research are disappearing worldwide. This means in general that there are fewer decision-making centers for vegetable breeding and cultivar development. This has also resulted in the focus on relatively few major vegetables produced worldwide, to the detriment of all the other cultivated vegetables. It is imperative that national governments and policymakers, as part of a social duty, invest in breeding research and cultivar development of traditional open-pollinated cultivars and in the minor and so-called "forgotten" vegetables. Developing vegetable cultivars that are more tolerant of environmental extremes should not be limited to only those of global importance. Many landrace vegetables from the tropics already are well adapted to the climatic conditions likely to be more widespread in the future. Many are highly nutritious and familiar to smallholder farmers, and can provide excellent opportunities to help farmers cope with climate change.

Smaller seed companies, which are usually specialize in few vegetable crops, must be supported, possibly through autonomous affiliation with the larger companies. More investments in this area will mean less expensive seed for growers to choose from, and an increased preservation of vegetable biodiversity. The accomplishment of this goal may require new approaches to vegetable breeding research and development by both the public and private sector.

Public plant breeding remains a key component of vegetable research systems worldwide, especially in developing countries. However, the increasing presence of private sector breeding and a decrease in national and international support make it difficult for the public sector to continue operating in the traditional manner. Declining funding for public vegetable breeding coupled with the rapid increase of vegetable production and consumption and an urbanizing population, has created a difficult situation. Public sector breeding must be strenghened. More public sector vegetable breeders are needed worldwide to select and to produce non-hybrid cultivars of the minor and "forgotten" vegetables. Breeding of vegetables and other minor crops must continue as a viable endeavor. Improving landrace vegetables is particularly important for the poorest. This will benefit small farmers, and will safeguard biodiversity and food security in developing countries.

Currently there are too few vegetable breeders to satisfy global demands and opportunities in the public and private sectors of developing and developed countries. In order to meet future needs, it is important that educational programs incorporate rapidly changing new technologies along with classical content and methods in order to meet professional needs for vegetable cultivar developers, researchers, teachers and support scientists.

Vegetable crop improvement powered through plant breeding is critical for sustainable production of vegetable crops that contribute to healthful diets and enhance quality of life for people around the world. Policymakers and investors have to turn their attention to enhanced funding for the vegetable and horticultural sector, allowing farmers to compete with their products on a world market increasingly determined by market quality standards and phytosanitary concerns and regulations. Many current vegetable breeding efforts remain under-funded and disorganized. There is a great need for a more focused, coordinated approach to efficiently utilize funding, share expertise, and continue progress in horticultural technologies and breeding programs. Only then will the silent vegetable and horticultural revolution currently underway benefit a significant portion of the world's poor nations, farmers, and landless laborers.

\section{REFERENCES}

[1] Dias, J.S. (2012) Major classes of phytonutriceuticals in vegetables and health benefits: A review. Journal of $\mathrm{Nu}$ tritional Therapeutics, 1, 31-62.

[2] Dias, J.S. (2012) Nutritional quality and health benefits of vegetables: A review. Food and Nutrition Sciences, 3, 1354-1374. http://dx.doi.org/10.4236/fns.2012.310179

[3] ACC/SCN. (2004) Fifth report on the world nutrition situation: Nutrition for improved development outcomes. United Nations ACC/SCN in collaboration with World Health Organization, Geneva.

[4] WHO. (2009) Global health risks: Mortality and burden of disease attributable to selected major risks. World Health Organization, Geneva.

[5] Hellen Keller International (HKI). (2010) Homestead food production model contributes to improved household food security, nutrition and female empowerment-Experience from scaling-up programs in Asia (Bangladesh, Cambodia, Nepal and Philippines). Nutrition Bulletin, 8, 1-8.

[6] Rao, S., Yajnik, C.S., Kanade, A., Fall, C.H.D., Margetts, B.M. and Jackson, A.A. (2001) Intake of micronutrientrich foods in rural Indian mothers is associated with the size of their babies at birth: Pune maternal nutrition study. The Journal of Nutrition, 131, 1217-1224.

[7] Dias, J.S. (2012) 1. Vegetable breeding for nutritional quality and health benefits. In: Carbone, K., Ed., Cultivar: Chemical Properties, Antioxidant Activities and Health Benefits. Nova Science Publishers, Inc., Hauppauge, New York, 1-81.

[8] Friel, C. and Baker, P.I. (2009) Equity, food security and health equity in the Asia-Pacific region. Asia Pacific Journal of Clinical Nutrition, 18, 620-632.

[9] Kays, S.J. and Dias, J.S. (1995) Common names of commercially cultivated vegetables of the world in 15 languages. Economic Botany, 49, 115-152. 
http://dx.doi.org/10.1007/BF02862917

[10] Kays, S.J. (2011) Cultivated vegetables of the world: A multilingual onomasticon. Wageningen Academic Publishers, Wageningen. http://dx.doi.org/10.3920/978-90-8686-720-2

[11] Dias, J.S. (2011) World importance, marketing and trading of vegetables. Acta Horticulturae, 921, 153-169.

[12] Dias, J.S. and Ryder, E.J. (2011) World Vegetable Industry: Production, breeding, trends. Horticultural Reviews, 38, 299-356.

[13] Monsanto. (2011) Supplemental toolkit for investors. Updated April 2011. Monsanto, St. Louis.

[14] Gale, F. (2002) China's food and agriculture: Issues for the 21st century. Market and Trade Economics Division, Economic Research Service. USDA, Washington DC.

[15] Rich, M. (2008) IPM program in Bangladesh wins award. Integrated Pest Management Collaborative Research Support Program.

[16] FAO. (2009) FAOSTAT data. Food and Agriculture Organization of the United Nations, Rome. http://www.fao.org.

[17] Senauer, B. and Goetz, L. (2003) The growing middle class in developing countries and the market for high-value food products. Economic Research Service. USDA, Washington DC.

[18] United Nations. (2007) World urbanisation prospects: the 2007 revision population database. United Nations Population Division, UN, New York.

[19] Reardon, T., Timmer, C.P., Barrett, C.B. and Berdegue, J. (2003) The rise of supermarkets in Africa, Asia, and Latin America. American Journal of Agricultural Economics, 85, 1140-1146. http://dx.doi.org/10.1111/j.0092-5853.2003.00520.x

[20] Yussefi, M. and Willer, H. (2003) The world of organic agriculture 2003-Statistics and future prospects. International Federation of Organic Agriculture Movements (IFOAM), Tholey-Theley.

[21] Willer, H. and Kilcher, L. (2009) The world of organic agriculture-Statistics and emerging trends 2009. FIBLIFOAM Report. IFOAM, Bonn, FiBL, Frick, Switzerland, ITC, Geneva.

[22] Raynolds, L.T. (2004) The globalization of organic agrofood networks. World Development, 32, 725-743. http://dx.doi.org/10.1016/j.worlddev.2003.11.008

[23] Regmi, A. and Gehlar, M. (2001) Consumer preferences and concerns shape global food trade. Global Food Trade, Food Review, 24, 2-8.

[24] FAO. (2007) FAOSTAT data. Food and Agriculture Organization of the United Nations, Rome. http://www.fao.org

[25] Bi, X., Dong, X., Huang, J., Hu, D. and Rozelle, S. (2004) Securing small producer participation in restructured national and regional agri-food systems-China Country Report. Regoverning Markets-Center for Chinese Agricultural Policy. Chinese Academy of Sciences, Beijing.

[26] Weinberger, K. and Lumpkin, T.A. (2005) High value agricultural products in Asia and the Pacific for smallholder farmers: Trends, opportunities and research priorities. GFAR, Rome.

[27] Deloitte. (2010) Emerging from downturn. Global powers of retailing. Deloitte.

[28] Deloitte. (2011) Leaving home. Global powers of retailing 2011. Deloitte.

[29] Manalili, N. and Tumlos, L.A.C. (2004) Regoverning market: Securing small producer participation in restructured national and regional agri-food system-Southeast Asia overview. Regoverning Markets. SEARCA, Los Banos.

[30] Shepherd, A. (2005) The implications of supermarket development for horticultural farmers and traditional marketing systems in Asia. FAO, Rome.

[31] Neven, D., Reardon, T., Chege, J. and Wang, H. (2006) Supermarkets and consumers in Africa: The case of Nairobi, Kenya. Journal of International Food \& Agribusiness Marketing, 18, 103-123. http://dx.doi.org/10.1300/J047v18n01_06

[32] Dias, J.S. and Ryder, E. (2012) Impact of plant breeding on the world vegetable industry. Acta Horticulturae, 935, 13-22.

[33] Lumpkin, T., Weinberger, K. and Moore, S. (2005) Increasing income through fruit and vegetable production opportunities and challenges. Consultive group on International agricultural research science Forum. CGIAR Priorities: Science for the Poor. CGIAR, Marrakech.

[34] Freedonia. (2010) World pesticide market. Freedonia Group Inc., Cleveland.

[35] OECD. (1997) Impacts of fruit and vegetable production on the environment and policy responses: European Union community instruments relating to the environmental aspects of the fresh fruit and vegetable sector. OECD, Paris.

[36] Osteen, C. (2003) Agricultural resources and environmental indicators: Pest management practices. In: Heimlich, R., Ed., Agricultural resources and environmental indicators, 2003. Agriculture Handbook AH722, Ch. 4.3. Washington DC.

[37] Pimentel D. (1997) Techniques for reducing pesticide use. Economic and environmental benefits. Wiley, New York.

[38] Mansour, S.A. (2004) Pesticide exposure-Egyptian scene. Toxicology, 198, 91-115. http://dx.doi.org/10.1016/j.tox.2004.01.036

[39] Choudhary, B. and Gaur, K. (2009) The development and regulation of Bt brinjal in India. ISAAA Brief 38, International Service for the Acquisition of Agri-Biotech Applications (ISAAA).

[40] European Food Safety Authority (EFSA). (2010) 2008 Annual report on pesticide residues according to article 32 of regulation (EC) no 396/2005. European Food Safety Authority Journal, 8, 1-442.

[41] Pimentel, D. and Hart, K. (1999) Ethical, environmental, and public health implications of pesticide use. New perspectives in bioethics. Johns Hopkins University Press, Baltimore.

[42] Dias, J.S. and Ortiz, R. (2012) Transgenic vegetable crops: 
Progress, potentials and prospects. Plant Breeding Reviews, 35, 151-246.

[43] Dias, J.S. and Ortiz, R. (2012) Transgenic vegetable breeding for nutritional quality and health benefits. Food and $\mathrm{Nu}$ trition Sciences, 3, 1209-1219. http://dx.doi.org/10.4236/fns.2012.39159

[44] Dias, J.S. and Ortiz, R. (2013) Transgenic vegetables for $21^{\text {st }}$ century horticulture. Acta Horticulturae, 974, 15-30.

[45] Wolf, J., Wijk, M., Cheng, X., Hu, Y., Diepen, C., Jongbloed, A., Keulen, H., Lu, C.H. and Roetter, R. (2003) Urban and peri-urban agricultural production in Beijing municipality and its impact on water quality. Environment and Urbanization, 15, 141-156.

[46] Zhang, W.L., Tian, Z.X., Zhang, N. and Li, X.Q. (1996) Nitrate pollution of groundwater in northern China. Agriculture, Ecosystems \& Environment, 59, 223-231. http://dx.doi.org/10.1016/0167-8809(96)01052-3

[47] Sheldrick, W.F., Syers, J.K. and Lingard, J. (2003) Soil nutrient audits for China to estimate nutrient balances and output/input relationships. Agriculture, Ecosystems \& Environment, 94, 341-354. http://dx.doi.org/10.1016/S0167-8809(02)00038-5

[48] Santamaria, P. (2006) Nitrate in vegetables: Toxicity, content, intake and EC regulation. Journal of the Science of Food and Agriculture, 86, 10-17. http://dx.doi.org/10.1002/jsfa.2351

[49] Dolan, C.S. and Humphrey, J. (2000) Governance and trade in fresh vegetables: The impact of UK supermarkets on the African horticulture industry. The Journal of Development Studies, 37, 147-176. http://dx.doi.org/10.1080/713600072

[50] Dolan, C.S., Humphrey, J. and Harris-Pascal, C. (1999) Horticulture commodity chains: The impact of the UK market on the African fresh vegetable industry. IDS Working Paper 96. IDS, Brighton.

[51] Putnam, J. and Allshouse, J. (2001) Imports' share of US diet rise in late 1990s. Food Review, 24, 15-21.

[52] FAO (2005) FAOSTAT data. Food and Agriculture Organization of the United Nations, Rome. http://www.fao.org

[53] Unnevehr, L.J. (2000) Food safety issues and fresh food product exports from LDCs. Agricultural Economics, 23, 231-240. http://dx.doi.org/10.1111/j.1574-0862.2000.tb00275.x

[54] Cerrex. (2003) Study of the consequences of the application of sanitary and phytosanitary (SPS) measures on ACP countries. Report commissioned by CTA. CTA. Cerrex Ltd, UK. 1-108.

[55] Grube, R.C., Radwanski, E.R. and Jahn, M. (2000) Comparative genetics of disease resistance within the Solanaceae. Genetics, 155, 873-887.

[56] Lacerrot, H. (1996) Breeding strategies for disease resistance in tomato with emphasis to the tropics: Current status and research challenges. 1st International Symposium Tropical Tomato Disease, Recife, 126-132.

[57] Zitter, T.A., Hopkins, D.L. and Thomas, C.E. (1996) Compendium of cucurbit diseases. Amer Phytopathological
Society Press, St. Paul.

[58] Gonsalves, D. (1998) Control of papaya ringspot virus in papaya: A case study. Annual Review of Phytopathology, 36, 415-437.

http://dx.doi.org/10.1146/annurev.phyto.36.1.415

[59] Thomas, P.E., Kaniewski, W.K. and Lawson, E.C. (1997) Reduced field spread of potato virus in potatoes transformed with the potato leafroll virus coat protein gene. Plant Disease, 81, 1447-1453. http://dx.doi.org/10.1094/PDIS.1997.81.12.1447

[60] Grafius, E.J. and Douches, D.S. (2008) The present and future role of insect-resistant genetically modified potato cultivars in IPM. In: Romeis, J., Shelton, A.M. and Kennedy, G.G., Eds., Integration of insect-resistant genetically modified crops within IPM programs. Springer Science p Business Media B.V., 195-221. http://dx.doi.org/10.1007/978-1-4020-8373-0 7

[61] Barrett, D.M., Garcia, E. and Wayne, J.E. (1998) Textural modification of processing tomatoes. Critical Reviews in Food Science and Nutrition, 38, 173-258. http://dx.doi.org/10.1080/10408699891274192

[62] Kang, H.M. and Saltveit, M.E. (2003) Wound-induced increases in phenolic content of fresh-cut lettuce are reduced by a short immersion in aqueous hypertonic solutions. Postharvest Biology and Technology, 29, 271-277. http://dx.doi.org/10.1016/S0925-5214(03)00043-7

[63] Ryder, E.J. (1999) Lettuce, endive, and chicory. CAB Intl., Wallingford.

[64] Hayes, H.K. and Garber, R.J. (1927) Breeding crop plants. McGraw-Hill, New York.

[65] Allard, R.W. (1960) Principles of plant breeding. Wiley, New York.

[66] Fehr, W.R. (1987) Principles of cultivar development. Vol.1 Theory and Technique. Macmillan, New York.

[67] Lincoln, R.E., Zscheile, F.P., Porter, J.W., Kohler, G.W. and Caldwell, R.M. (1943) Provitamin A and vitamin C in the genus Lycopersicon. Bot. Gaz, 105, 113-115. http://dx.doi.org/10.1086/335197

[68] Lincoln, R.E. and Porter, J.W. (1950) Inheritance of Betacarotene in tomatoes. Genetics, 35, 206-211.

[69] Tomes, M.L., Quackenbush, F.W., Nelson Jr., O.E. and North, B. (1953) The inheritance of carotenoid pigment systems in the tomato. Genetics, 38, 117-127.

[70] Gabelman, W.H. and Peters, S. (1979) Genetical and plant breeding possibilities for improving the quality of vegetables. Acta Horticulturae, 93, 243-270.

[71] Simon, P.W. (2000) Domestication, historical development, and modern breeding of carrot. Plant Breeding Reviews, 19, 157-190.

[72] Sudhakar, P., Singh, J., Upadhyay, A.K. and Ram, D. (2002) Genetic variability for antioxidants and yield components in pumpkin (Cucurbita moschata Duch. Ex Poir.), Vegetable Science, 29, 123-126.

[73] Frossard, E., Brucher, M., Mozafar, A. and Hurrell, R. (2000) Potential for increasing the content and bioavailability of $\mathrm{Fe}, \mathrm{Zn}$ and $\mathrm{Ca}$ in plants for human nutrition. Journal of the Science of Food and Agriculture, 80, 861- 
879.

http://dx.doi.org/10.1002/(SICI)1097-0010(20000515)80: 7<861::AID-JSFA601>3.0.CO;2-P

[74] Hotz, C. and McClafferty, B. (2007) From harvest to health: Challenges for developing biofortified staple foods and determining their impact on micronutrient status. Food and Nutrition Bulletin, 28, S271-S279.

[75] Fraser, P.D., Romer, S., Shipton, C.A., Mills, P.B., Kiano, K.W., Misawa, N., Drake, R.G., Schuch, W. and Bramley, P.M. (2002) Evaluation of transgenic tomato plants expressing an additional phytoene synthase in a fruit specific manner. Proceedings of the National Academy of Sciences of the United States of America, 99, 1092-1097. http://dx.doi.org/10.1073/pnas.241374598

[76] Mehta, R.A., Cassol, T., Li, N., Ali, N., Handa, A.K. and Mattoo, A.K. (2002) Engineered polyamine accumulation in tomato enhances phytonutrient content, juice quality and vine life. Nature Biotechnology, 20, 613-618.

[77] Premanchandra, B.R. (1986) Genetic regulation of carotene biosynthesis in selected tomato strains: Aspects of beta-carotene biosynthesis and B gene specificity. International Journal for Vitamin and Nutrition Research, 56, 35-43.

[78] Markovic, Z., Zdravkovic, J., Mijatovic, M. and Damjanovic, M. (2002) Breeding potential of local tomato populations for beta-carotene and vitamin C. Acta Horticulturae, 579, 157-161.

[79] Stommel, J.R., Abbott, J.A. and Saftner, R.A. (2005) USDA 02L1058 and 02L1059: Cherry tomato breeding lines with high fruit beta-carotene content. HortScience, 40, 1569-1570.

[80] Andre, C.M., Ghislain, M., Berlin, P., Oufir, M., Herrera, M.R., Hoffman, L., Hausman, J.F., Larondelle, Y. and Evers, D. (2007) Andean potato cultivars (Solanum tuberosum L.) as a source of antioxidant and mineral micronutrients. Journal of Agricultural Food and Chemistry, 55, 366-378. http://dx.doi.org/10.1021/jf062740i

[81] Brown, C.R., Culley, D., Yang, C.P., Durst, R. and Wrolstad, R. (2005) Variation of anthocyanin and carotenoid contents and associated antioxidant values in potato breeding lines. Journal of American Society Horticultural Science, 130, 174-180.

[82] Reyes, L.F., MillerJr, J.C. and Zevallos, L.C. (2005) Antioxidant capacity, anthocyanins and total phenolics in purple and red-fleshed potato (Solanum tuberosum L.) genotypes. American Journal of Potato Research, 82, 271277. http://dx.doi.org/10.1007/BF02871956

[83] Hanson, P.M., Yu, Y.R., Lin, S., Tsou, S.C.S., Lee, T.C., Wu, J., Jin, S., Gniffke, P. and Ledesma, D. (2004) Variation for antioxidant activity and antioxidants in subset of AVRDC-The World Vegetable Center Capsicum Core Collection. Plant Genetic Resources: Characterization and Utilization, 2, 153-166. http://dx.doi.org/10.1079/PGR200444

[84] Dickson, M.H., Lee, C.Y. and Blamble, A.E. (1988) Orangecurd high carotene cauliflower inbreds, NY 156, NY 163, and 165. HortScience, 23, 778-779.

[85] Simon, P.W. and Navazio, J.P. (1997) Early Orange Mass
400, Early Orange Mass 402, and Late Orange Mass, 404, High-carotene cucumber germplasm. HortScience, 32, 144145.

[86] Simon, P.W., Pollak, L.M., Clevidence, B.A., Holden, J.M. and Haytowitz, D.B. (2009) Plant breeding for human nutritional quality. Plant Breeding Reviews, 31, 325-392.

[87] de la Pena, R. and Hughes, J. (2007) Improving vegetable productivity in a variable and changing climate. International Crops Research Institute for the Semi-Arid Tropics, 4, 1-22.

[88] Porch, T.G. and Jann, M. (2001) Effects of high-temperature stress on microsporogenesis in heat sensitive and heat tolerant genotype of Phaseolus vulgaris. Plant, Cell \& Environment, 24, 723-731. http://dx.doi.org/10.1046/j.1365-3040.2001.00716.x

[89] Hazra, P., Samsul, H.A., Sikder, D. and Peter, K.V. (2007) Breeding tomato (Lycopersicon esculentum Mill) resistant to high temperature stress. International Journal of Plant Breeding, 1, 31-40.

[90] CGIAR. (2003) Applications of molecular biology and genomics to genetic enhancement of crop tolerance to abiotic stresses: A discussion document. Interim Science Council Secretariat, FAO, Rome.

[91] AVRDC. (1990) Vegetable Production Training Manual. Asian Vegetable Research and Training Center, Shanhua.

[92] Foolad, M.R. (2004) Recent advances in genetics of salt tolerance in tomato. Plant Cell, Tissue and Organ Culture, 76, 101-119. http://dx.doi.org/10.1023/B:TICU.0000007308.47608.88

[93] Shannon, M.C. and Grieve, C.M. (1999) Tolerance of vegetable crops to salinity. Scientia Horticulturae, 78, 5-38. http://dx.doi.org/10.1016/S0304-4238(98)00189-7

[94] Kuo, D.G., Tsay, J.S., Chen, B.W. and Lin, P.Y. (1982) Screening for flooding tolerance in the genus Lycopersicon. HortScience, 17, 76-78.

[95] Foolad, M.R. (1999) Comparison of salt tolerance during seed germination and vegetative growth in tomato by QTL mapping. Genome, 42, 727-734. http://dx.doi.org/10.1139/g98-163

[96] Rick, C.M. (1979) Potential improvement of tomato by controlled introgression of wild genes from wild species. Proc. Broadening the genetic base of crops. Wageningen, 3-7 July 1978, 167-173.

[97] Dias, J.S. (2010) Impact of improved vegetable cultivars in overcoming food insecurity. Euphytica, 176, 125-136. http://dx.doi.org/10.1007/s10681-010-0237-5

[98] Dias, J.S. (2010) 23.Impact of improved vegetable cultivars in overcoming food insecurity. In: Nath. P. and Gaddagimath, P.B., Eds., Horticulture and Livelihood Security. Scientific Publishers, Jodhpur, 303-339.

[99] Cavendish, W. (2000) Empirical regularities in the povertyenvironment relationship of poor households: Evidence from Zimbabwe. World Development, 28, 1979-2003. http://dx.doi.org/10.1016/S0305-750X(00)00066-8

[100] Weinberger, K. and Msuya, J. (2004) Indigenous vegetables in Tanzania: Significance and prospects. Technical Bulletin 31. AVRDC, Shanhua. 
[101] Gockowski, J., Mbazo’o, J., Mbah, G. and Moulende, T. (2003) African traditional leafy vegetables and the urban and peri-urban poor. Food Policy, 28, 221-235. http://dx.doi.org/10.1016/S0306-9192(03)00029-0

[102] Dias, J.S. (2011) Biodiversity and vegetable breeding in the light of developments in intellectual property rights. In: Grillo, O. and Verona, G., Eds., Ecosystems Biodiversity, Chapter 17. INTECH Publ., Rijeka, 389-428.

[103] Dias, J.S. (1989) The use of molecular markers in selection of vegetables. SECH, Actas de Horticultura, 3, 175181.

[104] Dias, J.S. and Ortiz, R. (2013) New Strategies and Approaches for Improving Vegetables Cultivars. In: Nath, P., Ed., The Basics of Human Civilization-Food, Agriculture and Humanity, Volume-I-Present Scenario. Prem Nath Agricultural Science Foundation (PNASF), Bangalore \& New India Publishing Agency (NIPA), New Delhi, 349381.

[105] Ryder, E.J. (2005) Intellectual property rights for plants. The case for a new law. Chronica Horticulturae, 45, 5-11.

[106] Dias, J.S. (2012) Impact of the vegetable breeding industry and intellectual property rights in biodiversity and food security. In: Jones, A.M. and Hernandez, F.E., Eds., Food security: Quality, management, issues and economic implications. Nova Science Publishers Inc., Hauppauge, 57-86.
[107] Dias, J.S. (2013) Impact of vegetable breeding industry and intellectual property rights in food security. In: Nath, P., Ed., The Basics of Human Civilization-Food, Agriculture and Humanity, Vol ume-I-Present Scenario. Prem Nath Agricultural Science Foundation (PNASF), Bangalore \& New India Publishing Agency (NIPA), New Delhi, 173-198.

[108] Hamilton, A., Lycett, G. and Grierson, D. (1990) Antisense gene that inhibits synthesis of the hormone ethylene in transgenic plants. Nature, 346, 284-287. http://dx.doi.org/10.1038/346284a0

[109] Oeller P.W., Wong, L.M., Taylor, L.P., Pike, D.A. and Theologis, A. (1991) Reversible inhibition of tomato fruit senescence by antisense RNA. Science, 254, 437-439. http://dx.doi.org/10.1126/science.1925603

[110] Klee, H.J., Hayford, M.B., Kretzmer, K.A., Barry, G.F. and Kishore, G.M. (1991) Control of ethylene synthesis by expression of a bacterial enzyme in transgenic tomato plants. Plant Cell, 3, 1187-1193.

[111] Good, X., Kellogg, J.A., Wagoner, W., Langhoff, D., Matsumura, W. and Bestwick, R.K. (1994) Reduced ethylene synthesis by transgenic tomatoes expressing $S$-adenosylmethionine hydrolase. Plant Molecular Biology, 26, 781-790. http://dx.doi.org/10.1007/BF00028848 